\title{
論「抴/曳」與「掣」的源流關係 及其在閩南、閩東若干方言的發展演變
}

\author{
杜佳倫 \\ 高雄・中山大學中文系 \\ raindoo@mail.nsysu.edu.tw
}

\section{提要}

本文藉由彙整、析論古漢語「把/曳」與「掣」的語義用法及其所處語詞杽生脈絡, 對照閩南、閩東若干 方言相關語詞的語義用法及其發展演變, 閩南方言以廈門話、台灣閩南語為例, 閩東方言則以福州話、馬 來西亞詩巫閩清話為例, 進而探究兩者之間密切的源流關係以及方言內部的個別發展。我們一方面彙整閩 南方言 $\mathrm{ts}^{\mathrm{h}} \mathrm{ua} 7 \mathrm{ts} \mathrm{s}^{\mathrm{h}} \mathrm{ua} 4$ 具體的語義用例, 同時也列舉閩東方言相應語詞的語義用例; 另一方面藉由爬梳古 漢語文獻來詳細探究漢語詞 $「$ 把/曳」與 $「$ 掣」的語義用法以及其音義杽乳關係; 最後從歷史音韻規則與 語義對應關係, 辨析漢語詞「把/曳/揱/泄」在閩語的發展與演變。

\section{關鍵詞}

閩語、把/曳、掣、同源詞、同族詞

1

前言*

根據《廈門方言詞典》（周長楫 $1998 ： 49$ ）的記錄, $\mathrm{ts}^{\mathrm{h}} \mathrm{ua} 7^{1}$ 此一語音形式有三種詞義用 法, 如表1所示：一是引領義, 例如 $\left\ulcorner\mathrm{ts}^{\mathrm{h}} \mathrm{ua} 7\right.$ 路」意指在前頭帶路, 該語詞被寫為方 言俗字 $「$ 宒」; 二是討娶義, 例如 $「 \mathrm{ts}^{\mathrm{h}} \mathrm{ua} 7$ 姥」意指娶老婆, 該語詞被寫為訓讀字

* 本文的發想起自 2013年國科會計畫「閩語古合口韻類的歷史層次分析（101-2410-H-110-063-）」所資助組織 的讀書討論會，感謝當時台灣大學中文系博士生助理譚家麒分享其對於閩南方言 $t s^{h} u a 7 一$ 詞的觀察與見 解, 引發我們對該語詞的關注; 後來 2016-2017年在進行馬來西亞詩巫閩清腔閩東話的實地調查時, 發現 閩東方言若干相應的語詞用法, 進而深覺該去聲語詞 $\mathrm{ts}^{\mathrm{h}} \mathrm{ua} 7$ 應延伸與入聲語詞 $\mathrm{ts}^{\mathrm{h}} \mathrm{ua} 4$ 進行系統性的音義演 變比較, 遂開始著力於本文之分析研究。本文初稿在 2018 年 07 月由紀念李方桂先生中國語言學研究學 會、中央研究院語言學研究所共同主辦的「紀念李方桂先生逝世三十周年第二屆李方桂學會青年學者 研討會」上口頭發表，由上海復旦大學盛益民教授導讀、提問，並獲得與會諸多前輩學者有益的建 議, 在此銘謝; 更要感謝《中國語言學集刊》兩位審查委員以及編輯部細心的審閱，提出詳實的批評 與指正，使本文得以補充更完整的論述，研究成果益趨完善。

1 本文聲調標記符號為：陰平-1、陰上-2、陰去-3、陰入-4、陽平-5、陽上-6、陽去-7、陽入-8。台灣閩南 語及閩東方言陽上調多與陽去調合流, 這時以「陽去 $-7 」$ 統稱; 而泉州方言陰去調與陽去調在箇讀時合 併, 這時以「陰去-3」統稱, 但連讀變調時兩者可以區分。 
$\left\ulcorner\right.$ 娶」 2 ; 三是不由自主排泄義，例如 $\left\ulcorner\mathrm{ts}^{\mathrm{h}} \mathrm{ua}\right.$ 尿」意指小孩子尿床，該語詞被寫為

$\ulcorner$ 拽」。根據《福州方言詞典》（馮愛珍1998：398、103-104）的記錄，福州話與上述語 詞相應者只有表排泄義的 $\ulcorner$ sie $7 」 ，$ 例如 $\ulcorner$ sie 7 尿」意指尿床，該語詞被寫為「泄」； 但表引領義乃使用「帶（tai7）」、表討娶義使用「討（ $\mathrm{t}^{\mathrm{h}} \mathrm{O2} ） 」 ，$ 此與廈門話表引領 義、討娶義的 $\mathrm{ts}^{\mathrm{h}} \mathrm{ua} 7$ 在語詞來源上顯然無關。

廈門話 $\mathrm{ts}^{\mathrm{h}} \mathrm{ua}$ ? $\mathrm{ts}^{\mathrm{h}} \mathrm{ua} 4$ 的相關語義用法及福州話相應語詞

\begin{tabular}{|c|c|c|c|c|}
\hline & \multicolumn{2}{|c|}{ 閩南（廈門） } & \multicolumn{2}{|c|}{ 閩東（福州） } \\
\hline （1）引領義 & 系 & ts ${ }^{\mathrm{h}}$ ua7 路（在前頭帶路） & \multicolumn{2}{|r|}{ （閩東使用另一語詞「帶」） } \\
\hline (2) 討娶義 & 娶 & ts ${ }^{\mathrm{h}} \mathrm{ua} 7$ 姥（娶老婆） & \multicolumn{2}{|r|}{ （閩東使用另一語詞「討」） } \\
\hline (3) 不由自主排泄 & 拽 & $\mathrm{ts}^{\mathrm{h}} \mathrm{ua} 7$ 尿（尿床） & 泄 & 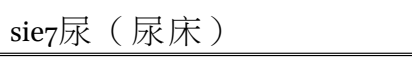 \\
\hline (4) 用力拉扯使斷 & 掣 & $\begin{array}{c}\text { 共索仔 } \mathrm{ts}^{\mathrm{h}} \mathrm{ua} 4 \text { 斷 } \\
\text { (把繩子扯斷) }\end{array}$ & 插 & 手 $\mathrm{ts}^{\mathrm{h}} \mathrm{ia} 4^{3}$ leo（手拉手） \\
\hline (5) 顫抖; 搖晃 & 㨻 & $\mathrm{p}^{\mathrm{h}} \mathrm{i} 88 \mathrm{p}^{\mathrm{h}} \mathrm{i} 88 \mathrm{ts}^{\mathrm{h}}{ }^{\mathrm{u}} \mathrm{a}_{4}$ (顫抖 ) & 忣 & 筋會 $\mathrm{ts}^{\mathrm{h}} \mathrm{ia} 4$ ( 拉傷 $)$ \\
\hline (6)失禁排泄義 & 掣 & ts ${ }^{\mathrm{h}} \mathrm{uaP4}$ 尿（小便失禁） & 泄 & $\operatorname{sie} 7$ 屎 \\
\hline
\end{tabular}

廈門話另有一語詞 $\mathrm{ts}^{\mathrm{h}} \mathrm{ua} 4$ 4（周長楫1998：405），文字上被寫為「掣」，大致分為三項 語義, 亦如表1所示：一是用力拉扯使之斷裂或分離, 受事賓語限定為柔軟細長之物,

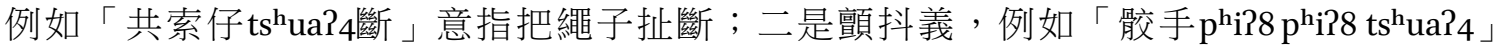
意指手腳顫抖；三是失禁排泄義，例如 $「 \mathrm{ts}^{\mathrm{h}} \mathrm{ua}$ 4尿」或 $\left\ulcorner\mathrm{ts}^{\mathrm{h}} \mathrm{ua}\right.$ 4屎」意指屎尿禁不住 而點滴泄出。福州話相應於上述語詞者有三：一是拉挽義的 $\left\ulcorner\mathrm{ts}^{\mathrm{h}} \mathrm{ia}\right.$ i 4$\lrcorner$, 例如「手 $\mathrm{ts}^{\mathrm{h}} \mathrm{ia} 4 \mathrm{leo} 」$ 意指手拉著手，該語詞被寫為「插」，近似廈門話 $\mathrm{ts}^{\mathrm{h}} \mathrm{ua}$ 4 4 的拉扯動作語 義，但用力程度不那麼強烈，且其所搭配的受事賓語類別也不相同; 二是扯動義的

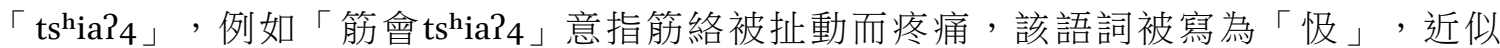
廈門話表顫抖義 $\mathrm{ts}^{\mathrm{h}} \mathrm{ua}$ 24 的狀態動詞用法，但語義發展有所差異; 三是表排泄義的 $\ulcorner\operatorname{sie} 7\lrcorner$, 例如 $\ulcorner$ sie7尿」或 $\ulcorner$ sie7屎」意指小便、大便失禁, 該語詞被寫為「泄」，相 對於廈門話語義有別的兩種讀法：以「 $\mathrm{ts}^{\mathrm{h}} \mathrm{ua}$ 尿」指稱小孩尿床，而以「 $\left\ulcorner\mathrm{ts}{ }^{\mathrm{h}} \mathrm{ua} 4 \mathrm{4}\right.$ 屎/ $\mathrm{ts}^{\mathrm{h}} \mathrm{ua} 4$ 尿」指稱大小便失禁, 福州話 $\operatorname{sie} 7$ 則同時指稱兩種語義, 沒有音讀上的區別。

表1所列廈門話、福州話六項語詞，在今日詞義用法上雖區別相當清楚，但就其歷 史音義演變脈絡來看, 應具有緊密的發展關係, 值得深入探究。4 本文所用以析論的

2 本文認為閩南方言討娶義的 $t s^{\mathrm{h} u a} 4$ 雖與漢語詞 $「$ 娶」語義用法相當, 但歷史音韻演變規則上無法合理聯 繫。《廣韻》收錄「娶」有二音讀：一為相俞切（中古心母 3 等虞韻平聲），釋義引《荀卿子》「問娶 之媒」; 二為七句切（中古清母 3 等遇韻去聲, 上古侯部）, 釋義引《說文》「取婦也」。第一音讀古 心母尚有可能在閩南方言讀為 $\mathrm{ts}^{\mathrm{h}}-$, 但韻讀、聲調皆不符合演變規則; 第二音讀古清母在閩南方言讀為 $\mathrm{ts}^{\mathrm{h}}$-沒有問題, 但中古虞韻組、上古侯部均無讀為- $\mathrm{ua}$ 的演變規則, 聲調上古全清去聲應歸讀陰去調, 而 非陽去調（泉州方言指稱娶妻之動詞, 箇讀為 $\mathrm{ts}^{\mathrm{h}} \mathrm{u}$ a3, 但連讀變調顯示該語詞本應來自古濁母去聲 者）。因此恐怕無法論證閩南方言討娶義的 $t s^{h} u a 7$ 與漢語詞「娶」具有同源關係。

3 福州方言的入聲韻尾已經合併為一套喉塞尾（-1)，我們在馬來西亞詩巫所調查的閩清腔閩東話顯示該 語詞原來應為舌根塞尾 ( - k ) 。

4 由於閩北方言多數使用不同詞源之語詞，如建甌方言（李如龍、潘渭水1998）表引領義使用「領(liaj8) 或邀(iaul)」，其中「領」也從引領隨帶義發展出照看小孩用法（領囝）；討娶義使用「討 $\left(\mathrm{t}^{\mathrm{h}} \mathrm{au} 2\right) 」$ ，與 
方言語料說明如下：綜合《中國語言地圖集》（1988）與《現代漢語方言概論》（侯 精一 2002）的分區結果，閩語大抵可分為六個次方言：閩南方言、莆仙方言、閩東方 言、閩北方言、閩中方言、瓊雷方言。根據《現代漢語方言概論》的細部分片：（1） 閩南方言分為四片：泉州腔為北片，漳州腔與潮汕腔合為南片，廈門、台灣漳泉混融 而成的閩南話獨立為東片，龍岩、漳平等受到閩西客話影響較深的閩南話則獨立為西 片；本文在廈門話若干語詞的基礎之上（表1），檢閱泉州、漳州、潮汕（澄海）、漳 平等方言, 發現均有同類語詞用法, 5 文中以筆者較方便進行調查檢證的台灣閩南語 作為詳細析論的語料。（2）閩東方言分為南、北兩片：南片包括福州、福清、古 田、閩清等方言點, 北片包括福安、壽寧、柘榮、霞浦等方言點; 本文在福州話若干 語詞的基礎之上（表1），檢閱福清、古田、福安、壽寧等方言語料，結果發現該類語 詞用法較集中出現在南片方言，6文中以筆者近年正在進行實地調查的詩巫閩清腔閩 東話做為詳細析論的語料。據此，在表1方言詞典所列語詞用法之基礎上，我們進而彙 整台灣閩南語的口說故事材料，以及近幾年在馬來西亞詩巫（Sibu）所調查的閩清腔 閩東話，7發現台灣閩南語同樣使用表1所列廈門話六項語詞，詩巫閩清話也使用表1所

閩東方言相同；表一般排泄義使用「nuع3尿/屎」，語義上與閩南 $\mathrm{ts}^{\mathrm{h}} \mathrm{ua} 24$ 、閩東 $\operatorname{sie} 7$ 的失禁義有所不同； 表發抖義則使用「抽( $\left.\mathrm{t}^{\mathrm{h}} \mathrm{iu1}\right) 」$ 。因此本文僅討論相關語詞在閩南、閩東若干方言的發展演變。不過, 值 得注意兩個語詞：（1）建甌方言表排尿失控時說 $\left\ulcorner\right.$ tsuع7尿」，第一音節倒是可以與閩南 $\mathrm{ts}^{\mathrm{h}} \mathrm{ua} 7$ 、閩東 $s i e 7$ 形成合理的同源對應關係。本文認為閩南 $\mathrm{ts}^{\mathrm{h}} \mathrm{ua}$ 、閩東 $\operatorname{sie} 7$ 應聯繫為餘制切的「泄去」（中古以母 3 等祭韻 去聲, 上古祭部），古以母在建甌方言有讀為 ts-的演變規則，如「餈（tsion8）」，上古祭部在建甌方

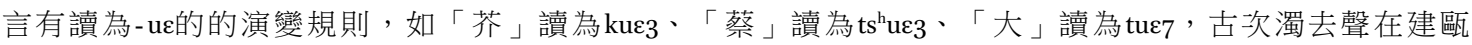
方言歸讀陽去調。據此, 建甌「tsuع7尿」在音義上可合理聯繫為「泄尿」。（2）建甌方言表拉豬尾巴

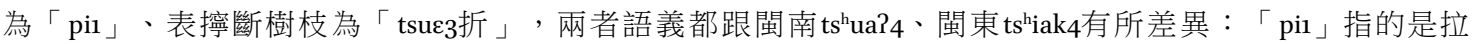

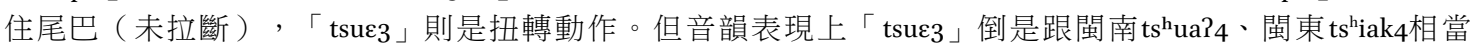
接近, 漢語詞「掣」有去聲讀（尺制切）（中古昌母 3 等祭韻去聲, 上古祭部）, 韻母、聲調均符合演 變規則，但古昌母在建甌方言理當讀為 $\mathrm{ts}^{\mathrm{h}}-$ ，這部分不符合規則，有待實地調查以更了解 $\ulcorner$ tsu 3 折」的 實際用法以及是否存在 $\left\ulcorner\mathrm{ts} \mathrm{t}^{\mathrm{h}} \varepsilon 3\right.$ 的方言變體。

5 除了泉州（林連通1993）、漳州（林寶卿1992、馬重奇1993）有一致的語詞用法。此外, 我們也檢閱漳平

（張振興1992）、澄海方言（林倫倫1996）的語料，但因方言調查報告所列語詞有限，很難找到完整的 對應語詞, 有待未來再親赴調查。就目前所得語料來看, 漳平指稱娶妻為 $\left\ulcorner\mathrm{ts}^{\mathrm{h}} \mathrm{ua} 3\right\lrcorner$, 澄海為 $\left\ulcorner\mathrm{ts}{ }^{\mathrm{h}} \mathrm{ua} 7\right\lrcorner$, 漳平指稱腹瀉亦為 $\left\ulcorner\mathrm{ts}^{\mathrm{h}} \mathrm{ua} 4\right.$ 屎」，澄海指稱尿床亦為 $\left\ulcorner\mathrm{ts}^{\mathrm{h}} \mathrm{ua} 7\right.$ 尿」，另有指稱拉扯動作亦為 $\left\ulcorner\mathrm{ts}^{\mathrm{h}} \mathrm{ua} 24\right\lrcorner$ 其 中漳平指稱娶妻為「 $\mathrm{ts}^{\mathrm{h}} \mathrm{ua} 3$ 」者, 聲調上歸讀為陰去調, 表面上看似與廈門、漳州、台灣閩南語不同, 實際上詳細分析漳平方言古濁母去聲的聲調演變規則，發現大部分歸讀11調（陽平調）或 53 調（陽去/陽 上調），而且前者多為白讀音，後者多為文讀音；另有少數歸讀24調（陰平調）、21調（陰去調）者; 非常有意思的是, 其中歸讀陰去調的語詞, 絕大多數都對應於閩東方言, 閩東方言有若干濁聲母去聲

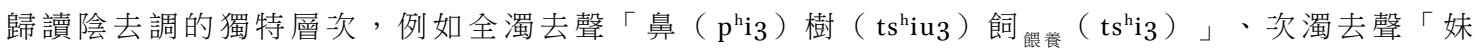
（muoi3）艾（ gia3）面（min3）」，杜佳倫（2014）辨析這類語詞多數聲母今讀帶有送氣徵性，或者在 閩南、閩北相應的聲母音讀為h-或s-, 因而提出該層次乃反映古閩越語的底層音韻痕跡。據此, 漳平方 言保有古濁母去聲歸讀陰去調的特殊層次, 與閩東方言一致。然則來自古以母祭部去聲的「把去/曳」在 漳平讀為 $\left\ulcorner\mathrm{ts}^{\mathrm{h}} \mathrm{ua} 3\right\lrcorner$ 亦是合於演變規則的音讀。

6 福清（馮愛珍1993）指稱尿床為 $\ulcorner$ sia3尿」，指稱流星為 $\ulcorner\mathrm{ts}$ hia3屎星」；古田大橋方言（秋谷裕幸、陳澤 平2012）指稱尿床亦為「sie7尿」，指稱流星為「天星 $\operatorname{sie} 3$ 窠」；但福安、壽寧等北片方言都指稱尿床為

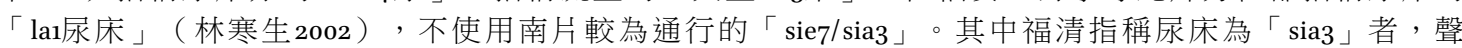
調上歸讀為陰去調, 亦符合前注所述閩東方言另有濁聲母去聲歸讀陰去調的獨特規律; 而古田似乎也 以聲母清濁來區別大量排泄義與失禁排泄義（與閩南相應），但還需要擴大調查確認「天星 $\operatorname{sie} 3$ 窠」的 詳細語義。此外, 檢閱這四個方言點語料都未列出 $\left\ulcorner\mathrm{ts}^{\mathrm{h}} \mathrm{ia} 4 \mathrm{~A}\right\lrcorner$ 的語詞用法, 這部分也有待未來親赴調查 確認。不過，詩巫閩清腔閩東話確實有與福州話用法一致的「 $\left.\mathrm{ts}^{\mathrm{h}} \mathrm{iak} 4\right\lrcorner$

7 二十世紀初中國閩東移民陸續跟隨教會前往馬來西亞墾殖, 第一次是1901年由閩清籍教會傳道黃乃裳帶 領大批閩清、古田一帶的移民前往東馬砂勞越的詩巫開墾聚居。近年來因閩東移民逐漸掌握當地經濟 核心，閩東話一躍成為當地通行語；東馬詩巫乃以閩清口音為主要通行腔調，其次為古田口音。 
列福州話四項相關語詞, 本文第二節乃以台灣閩南語、詩巫閩清話的實際語料為例, 更詳細地分析討論表1所列閩南、閩東方言相關語詞的語義用法。

本文將運用方言本字研究的尋音（梅祖麟 2000a）、探義（楊秀芳1999，楊秀芳 2000 ）、詞族研究（楊秀芳 2009）等系統性方法, 論證閩南方言 $t s^{\mathrm{h}} \mathrm{ua}$ 雖有三項詞義區 別，但實為同一詞族的玄乳衍生，從歷史音韻規則與語義對應關係來看，引領義、討 娶義的 $\mathrm{ts}^{\mathrm{h}} \mathrm{ua} 7$ 可以合理聯繫為漢語詞「把/曳餘制切」，排泄義的 $\mathrm{ts}^{\mathrm{h}} \mathrm{ua}$ 應聯繫為同一詞族 牽引義所杽生的「泄餘制切」; 閩南、閩東表拉扯義的 $\mathrm{ts}^{\mathrm{h}} \mathrm{ua} \mathrm{P}_{4} / \mathrm{ts}^{\mathrm{h}} \mathrm{iak} 4$ 確實應聯繫為漢語詞 $\left\ulcorner\right.$ 掣昌列切」, 閩南表顫抖義的 $\mathrm{ts}^{\mathrm{h}} \mathrm{ua} \mathrm{P}_{4}$ 、閩東表拉傷義的 $\mathrm{ts}^{\mathrm{h}} \mathrm{ua}$ ? 4 亦與之同源, 但語義發展 方向不同; 而閩南表失禁排泄義的 $t s^{\mathrm{h}} \mathrm{ua} 4$ 4較有爭議, 究竟應同樣聯繫為「掣昌列」, 或 是使用「泄」另一入聲讀法（私列切）來區辨語義, 這是我們打算詳細討論的課題。 為了妥善探究上述諸多閩語詞與漢語詞的同源關係, 本文也將辨析古漢語文獻中 $\ulcorner$ 把/曳」與「掣」的語義用法及其衍生脈絡，並進一步討論「抴/曳」與「掣」的語 詞源流發展關係。

以下第二節首先以台灣閩南語、詩巫閩清話的實際語料為例，彙整上述閩南 $\mathrm{ts}^{\mathrm{h}} \mathrm{ua}$ 、 $\mathrm{ts}^{\mathrm{h}} \mathrm{ua}$ 4具體的語義用例，同時也彙整閩東相應語詞的語義用例; 第三節則藉由 爬梳古漢語文獻來詳細探究「把/曳」與「掣」的語義用法，從而分析討論兩者的語詞 源流關係；第四節再從歷史音韻規則與語義對應關係，探討閩南、閩東方言相關語詞 與漢語詞「把/曳/掣/泄」的歷史音義對應性，以確立其同源關係以及閩語內部個別的 發展; 第五節總結本文研究成果。

閩南、閩東相關語詞的語義用法

如前所述，《廈門方言詞典》（周長楫1998）記錄閩南方言 $\mathrm{ts}^{\mathrm{h}} \mathrm{ua} 7$ 大致分有三種詞義用 法：一是引領義，二是討娶義，三是排泄義；另有表拉扯義、顫抖義、失禁排泄義的 $\mathrm{ts}^{\mathrm{h}} \mathrm{ua} \mathrm{P}_{4}$, 台灣閩南語也有相同的語詞用法。相應於此，《福州方言詞典》（馮愛珍 1998 ）記錄閩東方言 $\mathrm{ts}^{\mathrm{h} i a}$ 4分表拉挽義、扯動義，另有表排泄義的sie7，我們近年在馬 來西亞詩巫實際調查閩清腔閩東話，也有一致的語詞用法。本節主要彙整台灣閩南語 口說故事材料（胡萬川1996，1996-7，2001），並且對照早期明清戲文的相關句例，8依 據語義關聯分為三小節來分別探討前述閩南 $\mathrm{ts}^{\mathrm{h}} \mathrm{ua}$ 、 $\mathrm{ts}^{\mathrm{h}} \mathrm{ua} 4$ 的詳細語義用法及其發展演 變；同時也根據近年實際調查所得，具體說明閩東 $\mathrm{ts}^{\mathrm{h}} \mathrm{ia} \mathbf{2}_{4}$ 、sie 7 等相應語詞的語義用 法。

\section{1 表引領義、討娶義的 $\mathrm{ts}^{\mathrm{h}} \mathrm{ua} 7$}

本文認為閩南方言表引領義、討娶義的 $\mathrm{ts}^{\mathrm{h}} \mathrm{ua}$ 應具語義演變關係，本小節把兩者放在一 起進行討論。下面根據方言語料所呈現的語義用法細分為四小類來看：一是帶領義、 二是相攜隨帶義、三是娶妻義、四是引致義; 其中相攜隨帶義在台灣閩南語較為通 行，而引致義只出現在明清戲文，現代閩南方言的 $\mathrm{ts}^{\mathrm{h}} \mathrm{ua}$ 沒有這種用法。

8 明清戲文用例來自《荔鏡記》戲文, 《荔鏡記》為「陳三五娘」故事的戲劇文本, 使用潮州話及泉州 話混合寫成, 乃為最早一部閩南語白話文作品。《荔鏡記》的重要版本有：（1）明朝嘉靖丙寅年（四 十五年、1566）刊本《重刊五色潮泉插科增入詩詞北曲勾欄荔鏡記戲文全集》、（2）萬曆辛巳年刊本 《新刻增補全像鄉談荔枝記》、（3）清朝順治辛卯年刊本《新刊時興泉潮雅調陳伯卿荔枝記大全》、

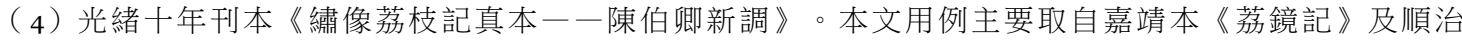
本《荔枝記》（吳守禮2001）。 
2.1.1＼cjkstart帶領義

（1）in1就 $\mathrm{ts}^{\mathrm{h}}$ ua7 伊去內面去予看。[他們就帶他去裡面看（父親生前睡床）]（梧棲鎮 一/山線賊合海線賊/118：21) 9

（2）抑無你 $\mathbf{t s}^{\mathbf{h}} \mathbf{u a 7}$ 我來看。[不然你帶我去看]（台南縣二/意子婿/198：18）

（3）伊嫏時伊老父 bat $4 \mathrm{ts}^{\mathrm{h}} \mathrm{ua} 7$ 來大寮遐，潘大番的墓……來培墓。[當時他父親曾經 帶他到大寮村潘大番的墓那邊掃墓]（台南縣二/潘大番/54：6-8）

（4）小七急媒姨入繡廳見啞娘。[小七帶媒人進繡房見小姐]（荔枝記/打媒姨/ $36: 22$ )

（5）娘仔、益春乞陳三琶走了。[小姐、益春被陳三帶走]（荔鏡記/登門逼婚/ $155: 16$ )

表引領義的 $\mathrm{ts}^{\mathrm{h}} \mathrm{ua}$ 做為動作動詞，後面經常隨帶賓語，例如（1）、（2）、（4）; 但 所引領的賓語也可以前置，例如（3）被帶來大寮村掃墓的是前置的「伊」，（5）被 帶走的是前置的「娘仔、益春」。表引領義的 $\mathrm{ts}^{\mathrm{h}} \mathrm{ua} 7$ 經常出現的完整句式為：「主

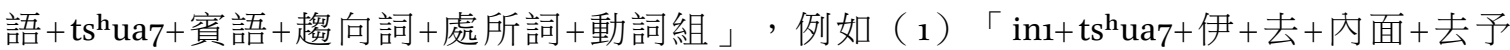
看」、（4）「小七+系+媒姨 + 入+繡廳 + 見啞娘」，乃由主語引領賓語趨往某處進行某 事, 語義著重於主語帶領賓語展開空間上的移動; 也可以不帶處所詞, 例如（2）

$\left\ulcorner\right.$ 你 $+\mathrm{ts}^{\mathrm{h}} \mathrm{ua} 7+$ 我+來+看」, 語義著重於主語帶領賓語進行某動作行為。無論是空間上 的帶領移動, 或是動作行為上的帶領進行, 這裡 ts $^{\mathrm{h}} \mathrm{ua}$ 均指向主語在前、賓語在後的帶 領意義。

\subsection{2 相攜隨帶義}

（6）線共針穿，步步相急（，引動人心情，切我守孤單）。[穿針引線，步步相攜] (荔鏡記/五娘刺繡/115：16)

（7）兩个母仔目 $\mathrm{ts}^{\mathrm{h}} \mathrm{ua}$ 去共彼姜子牙拜託。[母子倆相攜去跟姜子牙拜託]（梧棲鎮 一/大尾冊咬釣，細尾亟哥趒/6:6-7)

（8） 你 ts ${ }^{\mathrm{h}} \mathrm{ua} 7$ 這兩骹柴桶be?4創啥? [你帶著兩個木桶要做什麼]（梧棲鎮一/邱罔舍合 白賊七/200：12-13)

（9）我一个和尚的彼个啊呼， ts ${ }^{\mathrm{h}} \mathrm{ua} 7$ 這囝仔麼無方便啦。[我一個和尚的身分，帶這 小孩也不方便]（梧棲鎮一/關公的由來/6：8-9）

（10）伊平常時咧共儂 $\mathrm{ts}^{\mathrm{h}} \mathrm{ua} 7$ 目仔。[他平常在幫人帶小孩]（台灣閩南語調查所得）10

本文方言語料引用格式為「書目/篇名/頁碼：行數」，例如 $「$ 梧棲鎮一/山線賊合海線賊/118：21」即 指該語料來自《梧棲鎮閩南語故事集 $(一) 》$, 故事篇章為 $「 山$ 線賊合海線賊」，位於全書第118頁 之第21行。

10 審查委員指出泉州話指稱照顧小孩的說法是「kap4目仔」。根據《廈門方言詞典》解釋「kap4目 仔」（周長楫 $1998 ： 345$ ）本為將小孩抱在懷中，比喻為照看；另有 $\ulcorner$ kã 5 囝仔」（周長楫 $1998 ： 307$ ） 意指將小孩攜帶在自己身邊以照料看顧，「kã5」的動作語義為「將東西㨢到自己一邊」。而台灣閩 南語則較通行 $「 \mathrm{ts}^{\mathrm{h}} \mathrm{ua} 7$ 囝仔」, 其發展與「kã 5 囝仔」類似, $「 \mathrm{ts}^{\mathrm{h}} \mathrm{ua} 7 」$ 先由帶領動作轉向牽攜關係, 從而發展出隨帶在身邊的意思（此與kã5的基本語義相似）; 再由隨帶小孩詞彙化專指照顧小孩。本 文認為 $\mathrm{ts}^{\mathrm{h}} \mathrm{ua} 7$ 「帶領 $\rightarrow$ 隨帶 $\rightarrow$ 照料看顧」的發展並非模仿北方話, 而是跨語言之間的平行發展, 即便 是不會說標凖漢語的老輩發音人也是如此使用。此外，如閩北建甌方言使用「領囝（liaj8 kyin2）」

（李如龍、潘渭水1998：193）來指稱照看小孩，也是同類的平行發展。 
表帶領義的 $\mathrm{ts}^{\mathrm{h}} \mathrm{ua}$ 本指向一前一後的帶領動作, 由此進而發展出兩者之間相攜相牽的語 義，例如（6）本指線穿過針後、由針引領絲線進行縫繡動作，正因針引動線、線連 繫針，遂以「相丢」表達兩者互相牽攜的緊密關係；又如（7）亦指母子兩人相攜前 往拜託姜子牙。當 $\mathrm{ts}^{\mathrm{h}} \mathrm{ua}$ 由由一前一後的帶領動作轉向兩者的率攜關係, 便發展出表隨帶 的語義，此種用法在台灣閩南語較為通行，例如（8）意指主語隨身攜帶著兩個木 桶, （9）亦指和尚身邊帶著小孩, 這裡 $t^{\mathrm{h}}{ }^{\mathrm{h}} \mathrm{ua}$ 與上述前後帶領義有所不同, 但仍保有 主從的隨帶關係。其中所隨帶者若為小孩, 則進一步引申為照顧小孩, 例如（10）

$\left\ulcorner\mathrm{ts}{ }^{\mathrm{h}} \mathrm{ua} 7\right.$ 囝仔」，原來意指「隨帶孩子在身邊照顧」，如例（9）「我一个和尚…… $\mathrm{ts}^{\mathrm{h}} \mathrm{ua} 7$ 這目仔麼無方便」，這裡 $\mathrm{ts}^{\mathrm{h}} \mathrm{ua} 7$ 同時兼具隨帶義（身邊帶著這小孩）與照顧義 （照顧這小孩），而照顧孩子本即是隨帶在身邊，因此表隨帶義的 $\mathrm{ts}^{\mathrm{h}} \mathrm{ua}$ 後接賓語若為 小孩, 便專指照顧小孩。值得注意的是, 表隨帶照顧義的 $t$ s $^{\mathrm{h}} \mathrm{ua}$ 所出現的句式往往不帶 趨向補語, 若帶趨向補語則 $\mathrm{ts}^{\mathrm{h}} \mathrm{ua} 7$ 多表帶領義, 可比較 $「$ 伊逐工 $\mathrm{ts}^{\mathrm{h}} \mathrm{ua} 7$ 囝仔去公園要沙 仔」與「伊逐工佇厝 $\mathrm{ts}^{\mathrm{h}} \mathrm{ua} 7$ 囝仔」，前者表示她每天帶小孩去公園玩沙，這裡 $「 \mathrm{ts}^{\mathrm{h}} \mathrm{ua} 7$ 囝仔」為動詞組結構, $\mathrm{ts}^{\mathrm{h}} \mathrm{ua} 7$ 仍表帶領義，後接趨向補語說明帶領移動的空間目標；後 者表示她每天提攜、照顧小孩，這裡 $「 \mathrm{ts}^{\mathrm{h}} \mathrm{ua} 7$ 回仔」為複合動詞， $\mathrm{ts}^{\mathrm{h}} \mathrm{ua} 7$ 表隨帶照顧 義，後面不接趨向補語。

2.1.3 娶妻義

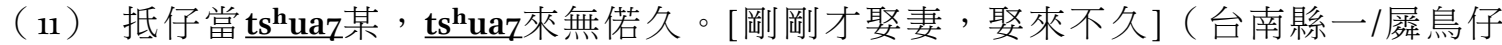
頭生菇/176: $5^{-6}$ )

（12）in1後生後禮拜 be?4 ts $^{\mathbf{h}} \mathbf{u a}$ 新婦矣。[他兒子下禮拜要娶媳婦了]（台灣閩南語調查 所得）

（13）約定只九月下急娘仔。[約定這個九月將要迎娶小姐]（荔鏡記/林大催親/ 140 : 13)

（14）林大爹便是, 近來卜息么。[林大爹最近要娶老婆]（荔枝記/林大催親/139：4）

（15）人說：「親家成冤家。」果然冤家成親家。「昨暮日陳都爺在知縣處。討一百 兩金, 來我厝為聘。陳都奶今旦卜來急我仔。今亦未知卜到未? 益春看茶乞伊 便。」（荔枝記/成親團圓/214：1-3）

表引領義的 $\mathrm{ts}^{\mathrm{h}} \mathrm{ua}$ 指向一前一後的帶領動作, 並由此發展出兩者之間相攜相率的語義, 後接賓語若為新娘、妻子、媳婦一類女性配偶, 則進一步引申為討娶義, 例如（11）、

（14）「 ts ${ }^{\mathrm{h}} \mathrm{ua} 7$ 某」、「暒么」皆意指娶妻，（12）「 $\mathrm{ts}^{\mathrm{h}} \mathrm{ua} 7$ 新婦」乃指娶媳婦，（13） $\left\ulcorner\right.$ ts ${ }^{\mathrm{h}} \mathrm{ua} 7$ 娘仔」則指迎娶小姐。與上述 $\left\ulcorner\mathrm{ts}^{\mathrm{h}} \mathrm{ua} 7\right.$ 目仔」相同，「 $\mathrm{ts}^{\mathrm{h}} \mathrm{ua} 7$ 某」亦已詞彙化專 指娶妻：「 $\mathrm{ts}^{\mathrm{h}} \mathrm{ua} 7$ 某」原來意指 $「$ 引領妻子進入家門」，例如 $\left\ulcorner\mathrm{ts}^{\mathrm{h}} \mathrm{ua} 7\right.$ 過門」或 $\left\ulcorner\mathrm{ts}^{\mathrm{h}} \mathrm{ua} 7\right.$ 入門」，又如例（15）「陳都奶今旦卜來系我仔」，這裡 $\mathrm{ts}^{\mathrm{h}} \mathrm{ua} 7$ 同時兼具引領義（帶領 我孩子入她家門）與討娶義（娶我孩子為媳婦），而討娶的傳統意義即是引領女性離 開娘家、進入丈夫家門，因此表引領義的 $\mathrm{ts}^{\mathrm{h}} \mathrm{ua}$ 後接賓語若為新娘、妻子、媳婦一類女 性配偶, 便專指討娶義。而討娶義的 $\mathrm{ts}^{\mathrm{h}} \mathrm{ua}$ 所出現的句式通常也不帶趨向補語, 可比較 $\left\ulcorner\right.$ 伊頂禮拜 $\mathrm{ts}^{\mathrm{h}} \mathrm{ua}$ 7 in1某去市場買菜」與 $「$ 伊頂禮拜 $t s^{\mathrm{h}} \mathrm{ua} 7$ 某」，前者表示他上星期帶太 太去市場買菜, 這裡 $「 \mathrm{ts}^{\mathrm{h}} \mathrm{ua} 7 \mathrm{in} 1$ 某」為動詞組結構, $\mathrm{ts}^{\mathrm{h}} \mathrm{ua}$ 仍表帶領義, 後接趨向補語 說明帶領移動的空間目標；後者表示他上星期娶妻，「 $\mathrm{ts}^{\mathrm{h}} \mathrm{ua} 7$ 某」為複合動詞， ts ${ }^{\mathrm{h}} \mathrm{ua} 7$

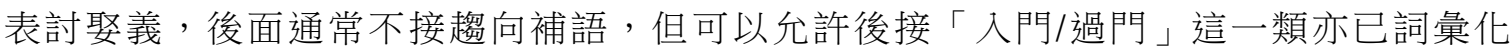
的趨向補語。 
2.1.4 引致用法

（16）猿啼鳥叫急人驚。[猿啼鳥叫使人心驚]（荔枝記/伯卿遊街/54：1）

（17）古畫掛二邊, 花香刍人愛。[花香使人心生喜愛]（荔枝記/伯卿掃厝/8o：8）

（18）見說仔兒返鄉里, 毛我心內七欣喜。[聽說孩兒將返故里, 使我內心欣喜]（荔 枝記/成親團圓/215：12)

（19）宅院清幽日頭長, 宒人平坦倚繡床。[宅院清幽日光長暖, 使人舒適倚躺繡床] （荔鏡記/園內花開/100：4）

明清戲文中的 $\mathrm{ts}^{\mathrm{h}} \mathrm{ua}$ 除了做為引領義、討娶義，另外有一特殊的引致用法，例如 （16）－（19）表示某事物情境引發某人發生某狀態或動作，句式均為「主語 $+\mathrm{ts}^{\mathrm{h}} \mathrm{ua} 7+$ 賓 語+動詞組」，主語可以是某事物，如例（17）「花香」，也可以是某動作情境，如例

（16）「猿啼鳥叫」、（18）「見說仔兒返鄉里」、（19）「宅院清幽日頭長」; 賓語 多是人稱詞; 動詞組多是狀態動詞「驚/愛/心內欣喜」，也可以是動作動詞「平坦倚 繡床」。從句式及語義來看, 引致用法的 $\mathrm{ts}^{\mathrm{h}} \mathrm{ua} 7$ 應從引領義發展而來：如前所述, 表引 領義的 $t s^{\mathrm{h}} \mathrm{ua} 7$ 經常出現的完整句式為: 「主語 $+\mathrm{ts}^{\mathrm{h}} \mathrm{ua} 7+$ 賓語 + 趨向詞 + 處所詞 + 動詞 組」，如例（4）「小七+宒+媒姨十入+繡廳+見啞娘」，語義著重於主語帶領賓語展開 空間上的移動; 也可以不帶處所詞, 如例（2）「你 $+\mathrm{ts}^{\mathrm{h}} \mathrm{ua} 7+$ 我 + 來 + 看」, 語義著重於

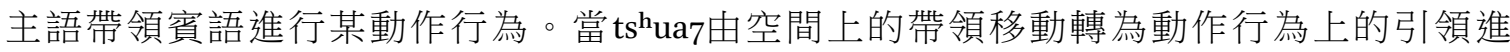
行，進一步語義焦點再移轉至後接的動詞組， ts ${ }^{\mathrm{h}} \mathrm{ua} 7$ 便產生引致用法；也就是由「主語 帶領賓語進行某動作行為」轉為「主語牽引賓語發生某狀態或動作」。不過, 現代閩 南方言的 $\mathrm{ts}^{\mathrm{h}} \mathrm{ua} 7$ 不具有這種引致用法。

表2 閩南方言表引領義、討娶義 $\mathrm{ts}^{\mathrm{h}} \mathrm{ua}$ 7的語義演變關係

\begin{tabular}{|c|c|c|c|c|}
\hline \multicolumn{3}{|c|}{ 動作動詞 } & & \multirow{2}{*}{$\begin{array}{c}\text { 詞彙化 } \\
\text { 隨帶照顧小孩 } \\
\text { ( ts }{ }^{\mathrm{h}} \mathrm{ua} \text { 回仔) }\end{array}$} \\
\hline \multirow[t]{3}{*}{ 帶領義 } & $\rightarrow$ & 隨帶義 & $\rightarrow$ & \\
\hline & $\rightarrow$ & $\rightarrow$ & $\rightarrow$ & 娶妻 (ts ${ }^{\mathrm{h}} u a 7$ 某) \\
\hline & $\rightarrow$ & 致使義 & & \\
\hline
\end{tabular}

總結本小節所討論閩南方言表引領義、討娶義 $\mathrm{ts}^{\mathrm{h}} \mathrm{ua}$ 的語義演變關係如表 2 ：

（1） ts ${ }^{\mathrm{h}} \mathrm{ua}$ 由由一前一後的帶領動作轉向主從的牽攜關係, 從而發展出隨帶義; 再由 隨帶義 $t s^{\mathrm{h}} \mathrm{ua} 7$ 搭配小孩一類賓語, 進而詞彙化專指隨帶照顧小孩。引領義 $\mathrm{ts}^{\mathrm{h}} \mathrm{ua} 7$ 通常後接趨向補語，表示帶領移動的空間目標或帶領進行的動作行為; 隨帶照 顧義 $\mathrm{ts}^{\mathrm{h}} \mathrm{ua}$ 則不接趨向補語。

（2） ts ${ }^{\mathrm{h}} \mathrm{ua}$ 由由前者引領後者的帶領動作，搭配女性配偶一類賓語，從而詞彙化專指 討娶義, 討娶義 $\mathrm{ts}^{\mathrm{h}} \mathrm{ua}$ 也往往不接趨向補語。

（3） ts ${ }^{\mathrm{h}} \mathrm{ua} 7$ 由「主語帶領賓語進行某動作行為」轉為「主語致使賓語發生某狀態或 動作」, 便產生致使用法, 但此用法只見於明清戲文。 


\section{2 表排泄義}

閩南方言表排泄義有兩個動作動詞： ts ${ }^{\mathrm{h}} \mathrm{ua} 7 \mathrm{ts}^{\mathrm{h}} \mathrm{ua} 4 \mathrm{4}$; 前者 $\mathrm{ts}^{\mathrm{h}} \mathrm{ua} 7$ 表示不由自主地排尿， 而且排泄的尿量頗多，例如（20）、（21）「 ts ${ }^{\mathrm{h}} \mathrm{ua}$ 尿」均指夜晚睡覺時不自主地排泄 大量尿液, 也就是 $「$ 尿床」。值得注意的是，表不由自主排泄義的 $\mathrm{ts}^{\mathrm{h}} \mathrm{ua}$ 只能排泄 $「$ 尿 液」, 而不能排泄粪便說「* $\mathrm{ts}^{\mathrm{h}} \mathrm{ua} 7$ 屎」。

（20）回仔暗時偷 $\mathbf{t s}^{\mathbf{h}} \mathbf{u a z}$ 尿。[小孩晚上尿床]（台灣閩南語調查所得）

（21）（爭）值一個十種, 倒大個水, 到落只腳川下度我。[哪一個雜種倒這麼多水 到這屁股下給我]（末）斬頭，是急尿了。起來。[（罵語），是你尿床了，起 來!]（荔枝記/阿媽尋五娘/167：7-8）

（22）伊 be7赴去便所tsuã9 ts ${ }^{\mathbf{h}} \mathbf{u a} \mathbf{4}$ 尿。[他來不及去廁所就尿失禁]（台灣閩南語調查所 得 )

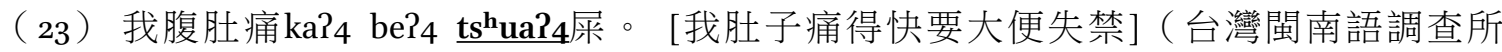
得 )

後者 $\mathrm{ts}^{\mathrm{h}} \mathrm{ua} 4$ 表示大小便失禁，如例（22）乃指因來不及上廁所而尿褲子，例（23）則 是腸胃不適而快要大便失禁。這裡的 $\mathrm{ts}^{\mathrm{h}} \mathrm{ua} 4$ 有禁忍不住而點滴排泄出屎尿之意, 其與 上述表不由自主排泄尿液的 $\mathrm{ts}^{\mathrm{h}} \mathrm{ua}$ 語義有幾點不同：（1） ts ${ }^{\mathrm{h}} \mathrm{ua}$ 乃指無意識下的不由 自主; $\mathrm{ts}^{\mathrm{h}} \mathrm{ua}$ 則往往是有意識的禁忍卻禁忍不住。（2） ts ${ }^{\mathrm{h}} \mathrm{ua} 7$ 只能排泄尿液; $\mathrm{ts}^{\mathrm{h}} \mathrm{ua} \mathrm{P}^{4}$ 則是可以排泄大小便。（3） ts ${ }^{\mathrm{h}} \mathrm{ua}$ 所排泄的是大量尿液； $\mathrm{ts}^{\mathrm{h}} \mathrm{ua}$ 則通常指向點滴 排泄。

閩東方言表失禁排泄義為 $\operatorname{sie}_{7}$, 該語詞既可以表示不由自主地排泄尿液，例如 （24）「sie7尿」意指尿床；也可以表示大小便失禁，例如（25）、（26）「sie7尿」、 $\ulcorner$ sie7屎」意指禁忍不住而排泄大小便，與此相近還可以使用另一動詞「漏（lau3）」， $\ulcorner$ 漏尿」、「漏屎」意指禁忍不住而滲漏大小便。據此, 閩南方言指稱小孩尿床為 $\left\ulcorner\mathrm{ts}{ }^{\mathrm{h}} \mathrm{ua} 7\right.$ 尿」，而指稱大小便失禁為 $\left\ulcorner\mathrm{ts}^{\mathrm{h}} \mathrm{ua} 4\right.$ 屎/ $\mathrm{ts}^{\mathrm{h}} \mathrm{ua} 4$ 尿」，兩者語義有別；而閩東方 言 $\operatorname{sie} 7$ 則同時指稱兩種語義，沒有音讀上的區別。

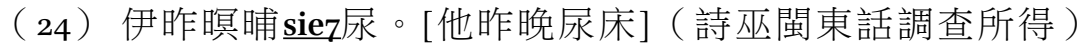

（25）伊 me7赴去粪坑， siez/漏尿loo。[他來不及去廁所而尿失禁]（詩巫閩東話調查所 得 )

（26）我腹肚痛, lo7 me7著糞坑, puok4 $\mathrm{k}^{\mathrm{h}} \varepsilon_{3}$ sie $/$ 漏单。[我肚子痛, 找不到廁所, 快 要大便失禁]（詩巫閩東話調查所得）

\section{3 表拉扯義、顫抖義}

本文認為閩南方言表拉扯義、顫抖義的 $\mathrm{ts}^{\mathrm{h}} \mathrm{ua} 4$ 應具語義演變關係，本小節把兩者放在 一起進行討論。而閩東方言有表拉扯義、扯動義的 $\mathrm{ts}^{\mathrm{h}}{ }^{\mathrm{i}} \mathrm{ak} 4$, 分別與閩南方言表拉扯 義、顫抖義的 $\mathrm{ts}^{\mathrm{h}} \mathrm{ua} / 4$ 相應。

\subsection{1 用力拉扯}

（27）雞仔ber4煤進前, 愛先共雞毛 $\mathbf{t s}^{\mathrm{h}} \mathbf{u a 2 4}$ 予清氣。[雞要水者之前, 必須先把雞毛拔 乾淨]（台灣閩南語調查所得）

（28）這電線足危險eo, mai3烏白 $\underline{t s}^{\mathbf{h}} \mathbf{u a} \mathbf{P 4}^{\circ}$ 。[這電線很危險, 不要隨便拉扯]（台灣閩南 語調查所得 ) 
（29）共電線 $\mathbf{t s}^{\mathbf{h}} \mathbf{i a k 4}$ 落來。[把電線大力扯下來]（詩巫閩東話調查所得）

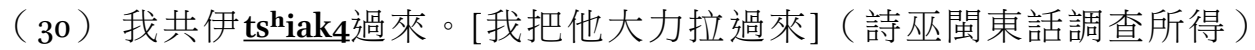

閩南方言表拉扯義的 $\mathrm{ts}^{\mathrm{h}} \mathrm{ua} 4 \mathrm{4}$ 乃做為動作動詞，賓語限定為毛髮、線、繩等一類細長 且柔軟的物品, 而且通常意指用力拉扯, 如例（27） ts ${ }^{\mathrm{h}} \mathrm{ua}$ 的賓語為「雞毛」，例

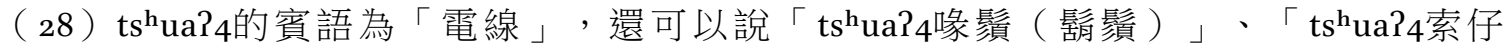
（繩子）」。相應於此, 閩東方言有表大力拉扯義的 $\mathrm{ts}^{\mathrm{h}} \mathrm{h}_{\mathrm{iak}}$, 但所接賓語條件與閩南 方言不盡相同：（1）閩東方言表拉扯義 $\mathrm{ts}^{\mathrm{h}} \mathrm{iak} 4$ 的賓語通常為線、繩一類，如例（29） $\mathrm{ts}^{\mathrm{h}} \mathrm{iak} 4$ 的賓語為「電線」，若拉扯的對象為毛髥一類，則動詞必須改用「拢（peik8）」;

（2） $\mathrm{ts}^{\mathrm{h}} \mathrm{iak} 4$ 拉扯的對象也可以是某人，如例（30），此時被拉扯的對象往往會因沒有 防備而嚇一跳, 相異於此, 閩南方言 $\mathrm{ts}^{\mathrm{h}} \mathrm{ua} 4$ 拉扯的對象不能是人。

2.3.2 抖動、扯動

（31）（我）就用這个烏的摃落, 你著愛假死啊, 愛倒咧啊, 倒得 $\mathrm{p}^{\mathrm{h}} \mathrm{i} 28 \mathrm{p}^{\mathrm{h}} \mathbf{1 8} \underline{\mathbf{t s}}^{\mathrm{h}} \mathbf{u a P 4}$ 。 [我就用這個黑棍子打下去，你就得裝死，要躺著不停顫抖]（梧棲鎮一/邱罔舍 合白賊七/186:6-7)

（32）紅頭的koP4對彼隻狗的尻脊骿安呢共摃一下，彼隻狗 $\mathbf{t s}^{\mathbf{h}} \mathbf{u a P 4}$ 一下，tsuã 9 走 去。[紅頭者又（用棍子）對那隻狗的背擊打一下，那隻狗因驚嚇而抖動一 下，就這樣跑走了]（梧棲鎮一/邱罔舍合白賊七/190：13-14）

（33）骹筋 $\underline{\text { ts }}{ }^{\mathbf{i}} \mathbf{i a k} 4$ 著/腰 $\underline{\mathbf{t s}}{ }^{\mathbf{h}} \mathbf{i a k} 4$ 過。[腳筋被扯傷/腰扭到（肌肉拉傷）]（詩巫閩東話調 查所得)

（34）伊雄雄行入來, 我 $\mathbf{t s}^{\mathbf{h}} \mathbf{u a 2 4}$ 一tio5。[他突然走進來, 我嚇一跳]（台灣閩南語調查 所得）

（35）伊無物件食, 喙箍咧 $\mathbf{t s}^{\mathbf{h}} \mathbf{u a 2 4}$ 。[他沒東西可吃, 嘴邊不停顫抖]（台灣閩南語調 查所得）

閩南方言表顫抖義的 $\mathrm{ts}^{\mathrm{h}} \mathrm{ua} 4$ 乃做為狀態動詞, 通常指向主語抖動的狀態, 可以是扯動

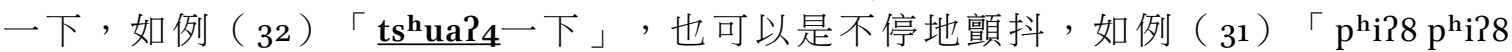
$\left.\underline{\mathbf{t s}^{\mathrm{h}} \mathbf{u a} \mathbf{4}}\right\lrcorner$ ，其中扯動一下往往引申為嚇一跳，例（32）「彼隻狗 $\mathbf{t s}^{\mathrm{h}} \mathbf{u a} \mathbf{4}$ 一下」乃指那 隻狗被棍子突如其來擊打而受到驚嚇, 其受驚嚇的反應為身體扯動一下。相應於此, 閩東方言也有表扯動義的狀態動詞 $\mathrm{ts}^{\mathrm{h}} \mathrm{iak} 4$, 如例（33）乃指腳筋、腰部肌肉因被用力拉 扯而受傷，但閩東方言的 $\mathrm{ts}^{\mathrm{h}} \mathrm{iak} 4$ 沒有表示顫抖的語義用法。

表3 表拉扯義、顫抖義 $\mathrm{ts}^{\mathrm{h}} \mathrm{ua} 4 \mathrm{~h} / \mathrm{ts}^{\mathrm{h}} \mathrm{iak} 4$ 的語義演變關係

\begin{tabular}{|c|c|c|c|c|}
\hline 動作動詞 & \multicolumn{4}{|c|}{ 狀態動詞 } \\
\hline \multirow[t]{2}{*}{$\begin{array}{l}\text { 用力拉扯義 } \\
\left(\mathrm{ts}^{\mathrm{h}} \mathrm{ua} 4 / \mathrm{ts}^{\mathrm{h}} \mathrm{iak} 4\right)\end{array}$} & $\rightarrow$ & $\begin{array}{l}\text { 扯動義 } \\
\left(\text { tshiak4 }^{\mathrm{h}}\right)\end{array}$ & & \\
\hline & $?$ & $\begin{array}{l}\text { 抖動義 } \\
\left(\text { tsh }^{\mathrm{h}}{ }^{2}{ }^{2} 4\right)\end{array}$ & $\rightarrow$ & $\begin{array}{l}\text { 顫抖義 } \\
\left(\mathrm{ts}^{\mathrm{h}} \mathrm{ua} 4 \mathrm{4}\right)\end{array}$ \\
\hline
\end{tabular}

本文認為閩東方言 $\mathrm{ts}^{\mathrm{h}}{ }^{\mathrm{iak}} 4$ 的拉扯義與扯動義應具語義演變關係，如表3所示：表示用力 拉扯的 $\mathrm{ts}^{\mathrm{h}} \mathrm{ua}$ 4/ $\mathrm{ts}^{\mathrm{h}} \mathrm{iak} 4$ 乃動作動詞，語義焦點著重在主語用力拉扯線、繩一類的條狀物 
充當的賓語; 若從反向角度切入觀察同一動作事件, 線、繩一類條狀物充當的賓語被 用力拉扯的結果可能是斷裂，閩東方言「骹筋 $\mathbf{t s} \mathbf{h i a k 4}$ 著」正是反映被拉扯的受事角 度, 腳筋亦屬條狀物, 因被用力拉扯而受傷, $\mathrm{ts}^{\mathrm{h}} \mathrm{iak} 4$ 乃由主動拉扯的動作動詞轉為表 示被扯動而受傷的狀態動詞。然而，閩南方言 $\mathrm{ts}^{\mathrm{h}} \mathrm{ua} 4$ 的拉扯義與顫抖義之間是否同樣 具語義演變關係，需要重新思考：

（1）根據閩東 $\mathrm{ts}^{\mathrm{h}} \mathrm{iak} 4$ 乃由主動拉扯的動作動詞轉為表示被扯動而受傷的狀態動詞, 倘若被拉扯的賓語擴大為某人或某動物，如閩東方言可說「共伊 $\mathbf{t s}^{\mathbf{h}} \mathbf{i a k} \mathbf{4}$ 過來」

（例30），人或其他動物突然被用力拉扯的結果，可能是受到驚嚇而身體抖 動，如「彼隻狗 $\mathbf{t s}^{\mathrm{h}} \mathbf{u a} \mathbf{2}$ 一下」（例 32 ）即反映那隻狗因突然受力而驚嚇、身體 抖動一下, 這樣說來, $\mathrm{ts}^{\mathrm{h}} \mathrm{ua}$ 4 亦可能由主動拉扯的動作動詞轉為表示因突然受 力而驚嚇抖動的狀態動詞; 不過較難解釋的是, 閩南方言 $\mathrm{ts}^{\mathrm{h}} \mathrm{ua}$ ? 的受事賓語不 能是某人或某動物，缺乏繼續發展為驚嚇抖動義的語義語法基礎。

（2）閩南方言表顫抖義 $\mathrm{ts}^{\mathrm{h}} \mathrm{ua} 4$ 的語義焦點已經傾向顫抖狀態本身，並不限定顫抖原 因一定是被外力拉扯，如例（34）顫抖原因乃受到突如其來的事件驚嚇而抖 動，又如例（35）顫抖原因乃無法吃到食物，此已不涉及拉扯動作語義。根據 古漢語文獻中「掣」乃由牽制義發展出引而縱之的抽動義，再發展出用力拉扯 義，本文認為閩南方言 $\mathrm{ts}^{\mathrm{h}} \mathrm{ua} 4$ 4的顫抖義應非來自拉扯義的後續演變，而是直承

$\ulcorner$ 掣」的抽動義而來（參見第三、四節討論）。

\section{3 古漢語「抴/曳」與「掣」的語義用法與源流關係}

本節藉由爬梳古漢語文獻來詳細探究「抴/曳」與「掣」的語義用法，11 並進一步討論 兩者的語詞源流關係。

\section{1 抴、曳}

漢語詞「抴、曳」皆從「厂」杽乳衍生, 兩者音義關係相當密切。根據《說文解字》 （例36），「厂」乃象「抴引」之形，段注說明「抴」釋義為「捈」，「捈」為橫而 引之（例 $37 、 38 ）$; 據此，「抴」」即「「」之本義，本為棤向率拉的具體動作，從 而引申出延長、牽引之義。《說文解字》另外收錄「曳」，從厂得聲（例39），段注 釋義為率引、拉長之義, 並認為厂不僅作為「曳」的聲符, 意義上也有密切關聯。

（36）《說文解字》厂，把也。……象抴引之形。凡厂之屬皆从厂。

《段注》：抴者，捈也。捈者，臥引也。臥引者，横引之。……若系从系、厂聲。 寫者短之。乃與右戻之J相溷。曳字从畡、厂聲。寫者亦不察、皆當攻正者也。12

（37）《說文解字》抴，捈也。从手世聲。

（a）《段注》：广下曰：把也。央下曰：束縛捽抴也。抴與曳音義皆同。……俗刻 誤从木。非也。《九歌》：桂擢兮蘭把。王逸曰：擢，楫也。抴，船旁板也。按《毛

11 本文所引用古漢語文獻, 主要檢索自中央研究院歷史語言研究所的「漢籍電子文獻資料庫」（http:// hanji.sinica.edu.tw/），特此銘謝。檢索結果都再一一複核書面文獻，所據書籍版本請參見引用文獻。

（漢）許慎撰, （清）段玉裁注：《說文解字注》, 臺北：藝文印書館, 1989 , 頁 633 。 
詩傳》云：楫所以擢舟也, 故因謂楫爲擢。擢者, 引也。船旁板曳於水中, 故因謂之 抴。俗字作櫂、作枻, 皆非是也。13

（b）《說文通訓定聲》：抴，捈也。从手世聲。與曳略同。……按：舟抴之而後行， 故所抴之具, 即名抴。14

（38）《說文解字》捈, 臥引也。从手余聲。

《段注》：臥引謂横而引之也。15

（39）《說文解字》曳, 央曳也。从卵厂聲。

《段注》: 央曳雙聲, 猶率引也。引之則長。故衣長曰曳地。……此形聲包會 意也。16

如例（37）所言，段玉裁認為「把」與「曳」音義皆同，而朱駿聲認為「把」與 $\ulcorner$ 曳」略同，意即不完全同義。耙梳古漢語文獻的用例，本文認為「抴」、「曳」雖 皆從「厂」衍生而來，但兩者早期的語義用法並不完全相同：（1）「把」在上古漢語 文獻中多指稱船獎，如例（40）「鼓枻而去」、（41）「桂櫂兮蘭枻」，參見例 （37）下引段玉裁、朱駿聲在解釋「把」時都特別說明：一般俗寫為「枻」者本應作 $\ulcorner$ 把」, 指稱在船旁邊撥水前進的用具, 即今所謂船獎, 由於船獎乃在水中棤向划 動、牽引船隻，故稱之為「把」；而寫為「櫂」者本應作「擢」，為拉引的動作，由 於舟楫乃用來引動船隻的工具，故稱之為「擢」。這樣看來，「擢（櫂）」指稱一般 引舟而行的船楫，而「抴（枻）」則專指船旁撥水、率引船隻前進的短獎，17到了宋 代蘇軾《赤壁賦》中則改稱「桂棹兮蘭獎」。（2）由於「把」指稱船旁撥水的短 獎, 一方面用以牽引船隻前進, 另一方面船夫亦可伸出短獎以率引乘客上舟, 故例 （42）乃言「度已以繩」、「接人用抴」，也就是說審度自己的行為舉止要以嚴格的 法則為準, 而與他人來往則要以寬和的引導方式。這裡「把」乃從具體的船獎引伸為 牽引他人之義。18

（40）《楚辭・漁父》漁父莞爾而笑，鼓枻（抴）而去。19

\footnotetext{
13 《說文解字注》, 頁 616 。

14 （清）朱駿聲撰：《說文通訓定聲》, 臺北：京華書局, 1970 , 頁 576 。

15 《說文解字注》, 頁616。

16 《說文解字注》, 頁 754 。

17 根據《集韻》「槳」之釋義：《方言》「所以隱櫂謂之槳」。一說前推曰「槳」，卻曳曰「櫂」

（宋·丁度等編《集韻》, 臺北：學海出版社， 1986 , 頁 413 ）。又根據《正字通》「槳」之釋義：行 舟具, 長大曰「櫓」, 短小曰「槳」; 縱曰「櫓」, 横曰「槳」（明 $\cdot$ 張自烈撰, 清 - 廖文英編：

《正字通》, 北京：中國工人出版社, 1996 , 頁 $528 ） 。 由$ 此可見, 「槳」具幾項專有特點：短小、横 向撥水、往前推動，上古漢語稱之為「枻（抴）」。而「櫂（擢）」則指向後拖曳的一般船楫。

18 有審查委員提問：「「、抴等字到底是用作名詞還是動詞？」本文認為《說文》解釋為象形者未必 均是名詞用法, 例如「大、飛」等, 文字創意雖為象形方法, 但該語詞皆非名詞用法; 語詞的詞性 用法理當落實到文獻中的詞例分析，且同一語詞很可能因所處句法位置而有不同詞性的用法，例如 $\ulcorner$ 解衣衣我」。據此來看以「「」為核心語義發展而出的「把去, 曳」，上古漢語文獻乃呈現 $\ulcorner$ 把去」多為名詞用法, 但也有少數動詞用法（把慧星），而「曳」則一律為動詞用法。本文4.1節將 討論閩南語 $\mathrm{ts}^{\mathrm{h}} \mathrm{ua}$ 在語義上接近表牽引義的 $「$ 把去」, 在語法表現上則接近 $「$ 史」, 著眼於「把去、 曳」的同族語詞關係, $\mathrm{ts}^{\mathrm{h}} \mathrm{ua}$ 可以合理與該詞族聯繫, 同樣源於拉引的核心語義, 發展出牽引之義, 但語法表現上乃做為動詞使用。
}

（漢）劉向編集，（清）王逸章句：《楚辭》，北京：中華書局，1985，頁90。 
（41）《楚辭・九歌・湘君》桂櫂（擢）兮蘭枻（抴），㗀冰兮積雪。20

（42）《荀子 · 非相》故君子之度已則以繩, 接人則用抴。度已以繩, 故足以為天下 法則矣；接人用抴，故能寬容，因求以成天下之大事矣。

楊倞注：抴，荤引也。21

（3）相異於上述「把」的語義用法，「曳」在上古漢語文獻中並未指稱率引之義, 而多是拖曳後物之義, 如例（43）「行不舉足，車輪曳踵」意指手執君器及幣玉行走 時, 腳不能完全離地, 必須抬起前腳、拖著臉跟, 像輪子拖地行走一樣。「曳」為動 作動詞, 後接受事賓語, 如例（44）-（47），後面可拖曳拐杖、兵器、尾巴、彗星， 且所拖曳之器物往往屬於主事者所有，不具有反向的抗力；例（48）「曳地」乃指衣 長而拖在地上, 「地」則非被拖拉的受事者, 而是指向處所, 但所拖曳之衣物同樣不 具有反向的抗力。

（43）《禮記・曲禮下》執主器, 操幣圭璧, 則尚左手, 行不舉足, 車輪曳踵。

《正義》日：又明提擧用手足之儀也。圭璧，瑞玉也。尚，上也。謂執持君器及幣 玉也。若擎奉此物則右手在下, 左手在上, 左尊, 故云尚左手。行不舉足車輪曳踵 者：曳, 拽也。踵, 腳後也。若執器行時則不得舉足, 但起前拽後, 使踵如車輪曳地 而行, 故云 : 「車輪史踵」。22

（44）《禮記・檀弓上》孔子蚤作，負手曳杖，消搖於門。23

（45）《孟子・梁惠王上》兵刃既接, 棄甲曳兵而走。24

（46）《莊子・秋水》此龜者, 寧其死為留骨而貴乎? 寧其生而曳尾於塗中乎? ${ }^{25}$

（47）《楚辭・九靯·怨思》曳彗星之皓旰兮，撫朱爵與鵔鸃。26

（48）《史記・孝文本紀》令衣不得曳地, 幃帳不得文繡, 以示敦朴, 為天下先。27

根據以上析論，「把」、「曳」在上古漢語的語義用法並不完全相同，「把」多為名 詞用法, 指稱率引向前的船獎; 「曳」則意指後頭拖曳某物的動作。不過, 例（49） $\ulcorner$ 抴彗星」相應於例（47）「曳彗星」，這裡「抴」相當於「曳」乃拖曳後物之義, 意指後頭拖著彗星如同旌旗上垂飾的燕尾羽毛，而《集解》所注「連経」之義乃承前 句而言：氣如雄雞的旬始星懸垂如同旌旗上的飄帶, 而曳長的彗星如同綴飾於飄帶上 的燕尾羽毛。

（49）《史記・司馬相如列傳》垂旬始以為幓兮，抴彗星而為髹。

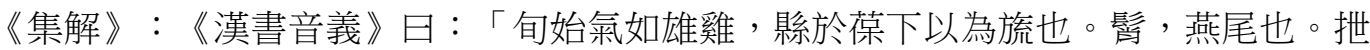
彗星，経著旒以為燕尾。」28

\footnotetext{
20 《楚辭》, 頁 27 。

21 （周）荀況撰，（唐）楊倞注：《荀子》。北京：中華書局，1985。頁 80 。

22 （漢）鄭元注，（唐）孔䫋達等正義：《禮記注疏》，臺北：新文豐出版社， 2001 , 頁 171 。

23 《禮記注疏》, 頁330。

24 (漢) 趙岐注，（宋）孫南疏：《孟子注疏》，臺北：新文豐出版社，2001，頁 33 。

25 （周）莊周撰, (晉) 郭象注, （唐）陸德明釋文, （唐）成玄英疏, (清) 郭慶藩集釋 : 《莊子 集釋》，臺北：臺灣中華書局，1980，頁 315 。

26 《楚辭》, 頁 171 。

27 (漢) 司馬遷撰, (南朝宋) 裴駰集解, （唐）司馬貞索隱, 張守節正義：《史記附札記》, 臺 北：鼎文書局，1979，頁 433 。

28 《史記附札記》，頁 3057 。
} 
東漢以後, 「曳」由拖曳後物衍生出用力拖拉的動作語義，如例（50）-（53）均是指 向用力拖拉某人或某動物，例（50）「走卒前曳下堂皇」意指士兵向前將監御史拉下 公堂, 例（51）「使人曳著泥中」乃遣人將奴婢用力拖拉至泥土地上，例（52）

曳遐墜地」乃用力拖拉裴遐而使之墜地，例（53）「復令步人拖曳」乃用力拖拉狗 犬；這裡「曳」多後接具有反向抗力的受事賓語，明顯相異於前例（44）-（48）。

（50）《漢書・楊胡朱梅云列傳 - 胡建》建從走卒趨至堂皇下拜謁, 因上堂〔皇〕, 走卒皆上，建指監御史曰：「取彼。」走卒前曳下堂皇。建曰：「斬之。」遂 斬御史。29

（51）《世說新語・文學》鄭玄家奴婢皆讀書。嘗使一婢不稱旨，將撻之。方自陳 說，玄怒，使人曳著泥中。30

（52）《世說新語 - 雅量》遐與人圍棊, 馥司馬行酒, 正戲, 不時為飲。司馬恚, 因曳遐墜地。遐還坐, 舉止如常, 顏色不變, 復戲如故。31

（53）《搜神記・華佗》以繩繫犬頸，使走馬牽犬，馬極軴易，計馬走三十餘里，犬 不能行, 復令步人拖曳, 計向五十里。32

東漢以後「把」在一般漢語文獻中較不常使用, 主要出現於東晉以後的漢譯佛經中, 同樣指稱用力拖拉、甚至是拉扯的動作語義，如例（54）「䶗嚙拖抴」意指㥪狼以利 齒嚙咬、用力拖拉地獄罪人，「拖把」相應於例（53）「拖曳」，「把」、「曳」二 詞語義十分相近；但漢譯佛經中「抴」往往表示比拖拉程度更嚴重的用力拉扯之義, 如例（55）「抴裂我衣」意指扯裂我的衣服、（ $56 ） 「$ 不忍抴挽」意指親生母親愛護 其子而不忍心用力把小孩拉扯過來，這裡「抴」乃指向「用力扯動而欲使之斷裂或分 離」, 語義略異於前述例（50）-（53）「曳」的拖拉某物之義；但十分相近於另一語

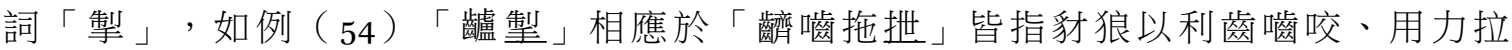
扯，下節將另外討論「掣」的語義用法。

（54）《大藏經 - 佛說長阿含經 - 地獄品》犲狼地獄縱廣五百由旬, 罪人入已, 有群

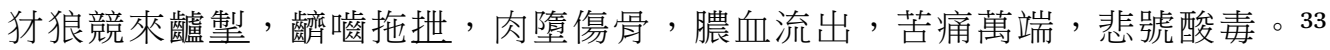

（55）《大藏經 · 賢愚經 - 無惱指镘緣》自汝去後, 常見侵陵, 我適不從, 抴裂我 衣, 壊我身首。34

（56）《大藏經 - 賢愚經 - 檀䐣䩭緣》其非母者, 於兒無慈, 盡力頓牽, 不恐傷損; 所生母者, 於兒慈深, 隨從愛護, 不忍抴挽。35

29 （漢）班固撰，（唐）顔師古注：《漢書》, 臺北：鼎文書局，1979，頁 2910。

30 (南朝宋) 劉義慶撰, (梁) 劉孝標注, 朱鑄禹彙校集注：《世說新語彙校集注》, 上海：上海古 籍出版社, 2002 , 頁 171 。

31 《世說新語彙校集注》, 頁 306 。

32 (晉) 干寶撰, 曹光甫、王根林校點：《搜神記》, 上海：上海古籍出版社, 2012 , 頁 38 。

33 ( 後秦) 佛陀耶舍、釋佛念譯 : 《佛說長阿含經》, 收錄於《乾隆大藏經》第五十冊, 臺北：新文 豐出版社, 1998 , 卷十九, 頁 503 。

34 ( 北魏) 釋慧覺譯 : 《賢愚經》, 收錄於 《中華大藏經》第五十一冊, 上海：中華書局，1992，卷十 一, 頁 164 。

35 《賢愚經》, 卷十一, 頁 171 。 
跟表用力拖拉或拉扯義的 $「$ 曳/抴」音義關係相近的語詞還有「拽」，如例（57）與前 例（50）乃反映「拽」等同於表用力拖拉動作的「曳」，惟字形上添加了標誌手部動 作的義符; 再如例（58）「手把其尾, 拽而出之」意指用手握著蛟尾將之拉扯出來, 例（59）「以口拽純衣」意指狗以嘴巴用力拉扯純的衣服，例（60）「手拽教伊入」 意指以手用力拉他進來，例（61）「掣拽」並列出現。「拽」出現在東漢以後的一般 漢語文獻中，與只出現在漢譯佛經、同樣表用力拉扯義的「抴」形成互補分布。《說 文解字》、《廣韻》都沒有收錄「拽」; 而《廣韻》收錄「把」兩種音讀：一是餘制 切（以母祭韻去聲），二是羊列切（以母薛韻入聲）, 後者釋義下說明「亦作拽, 拕 也」。36 由此可見，表用力拉扯義的「抴」、「拽」實乃同一語詞。

（57）《說苑・指武》建從走卒趨至堂下拜謁, 因上堂, 走卒皆上, 建䟜指監御史 曰：「取彼。」走卒前拽下堂。建曰：「斬之。」遂斬監御史，護軍及諸校皆 愕驚, 不知所以。37

（58）《論衡 - 龍虛》當薔丘訢之殺兩蛟也, 手把其尾, 拽而出之, 至淵之外, 雷電 擊之。38

（59）《搜神記 - 義犬塚》信純臥處, 恰當順風, 犬見火來, 乃以口拽純衣, 純亦不 動。39

（60）《祖堂集・安國和尚》把手拽教伊入，爭奈不肯入! 40

（61）《敦煌變文・佛說阿彌陀經講經文》雲擎樓閣下長空, 制拽羅衣來入會。41

表4 「把/曳/拽」的語義發展演變

\begin{tabular}{|c|c|c|c|c|c|c|}
\hline \multicolumn{2}{|c|}{ 抴/电/拽 } & \multicolumn{3}{|c|}{ 受事者 } & 力量大小 & 施力者 \\
\hline 牽引義 & 抴舟 & [-反抗力] & [+移動 ] & $\begin{array}{l}\text { [-施力者所 } \\
\text { 有] }\end{array}$ & [抗力<施力] & [土隨帶受事] \\
\hline 拖曳後物義 & 曳尾 & [-反抗力] & [+移動 ] & $\begin{array}{l}\text { [+施力者所 } \\
\text { 有 }]\end{array}$ & [抗力<施力] & [+隨帶受事] \\
\hline 用力拖拉義 & $\begin{array}{l}\text { 曳殿墜地 } \\
\text { 前拽下堂 }\end{array}$ & [+反抗力] & [+移動] & $\begin{array}{l}\text { [-施力者所 } \\
\text { 有] }\end{array}$ & [抗力<施力] & [+隨帶受事 $]$ \\
\hline 用力拉扯義 & $\begin{array}{l}\text { 把裂我衣 } \\
\square \text { 拽純衣 }\end{array}$ & $\begin{array}{l}\text { [ } \text { 反抗力 }] \\
\text { (固著重力 ) }\end{array}$ & [+移動/斷裂] & [-施力者所有] & [抗力<施力] & [-隨帶受事] \\
\hline
\end{tabular}

36 （宋）陳彭年等編撰：《廣韻》，臺北：洪葉文化， $2001 ，$ 頁 378 、 500 。

37 (漢) 劉向撰 : 《說苑》, 臺北：臺灣中華書局, 1981 , 卷十五, 頁 4 。

38 （漢）王允撰：《論衡》, 北京：中華書局, 1985 , 卷六, 頁 66 。

39 《搜神記》, 頁 157 。

40 (南唐) 靜、筠二禪師編撰, 孫昌武、衣川賢次、西口芳男點校：《祖堂集》, 北京 : 中華書 局, 2007 , 頁 $485^{\circ}$

41 潘重規編著：《敦煌變文集新書》，臺北：文津出版社，1994，頁 177 。 
總合以上討論 $「$ 抴/曳/拽」語義用法的發展演變如表 4：

（1）「抴」本為棤向率引之義, 在上古漢語文獻中多寫為「枻」, 專指船旁撥水、 率引船隻前進的短獎, 引申為牽引他人之義。《廣韻》收錄「枻」為餘制切, 與「把」的第一種音讀相同。42

（2）「曳」為拖曳後物之義，《廣韻》收錄也是餘制切。43 本文認為雖然「把」、

$\ulcorner$ 曳」兩詞皆從「厂」杽乳衍生，但上古漢語文獻中兩詞語義略有不同，與其 所涉及的受事賓語類別有關：「把」多為名詞用法，用它來牽引的受事者（船 隻或渡客）並非施力者所擁有的一小部分，因此施力者乃荤引受事者前進，而 不見得隨帶受事者在身旁：相對於此，「曳」為動詞用法，其受事賓語多為施 力者所擁有的一小部分（腳踵、尾巴、拐杖、兵器），因此施力者乃隨帶受事 者在身後，此即拖曳之義。

（3）本文認為「抴/拽」的用力拉扯義乃衍生自「曳」的拖曳義之進一步發展：東 漢以後「曳」的受事賓語擴展至非施力者所擁有，且多為具有反向抗力的某人 或某動物，因而語義上由拖曳後物轉為用力拖拉，但施力者還是隨身拖拉著受 事者；受事賓語的逐步擴展進而促使拉動的對象也可以是非施力者所擁有、又 不具反向抗力的外部物品，例如衣物、屍體、小孩，但這類受事賓語有其原 來固著之處的重力，拉扯動作往往欲使之從原來固著處斷裂或分離，且施力者 並不隨身帶著受事者。為了與主要做為拖曳後物義的「曳」相區別，遂後起提 手旁的「拽」來標記用力拖拉或用力拉扯之動作語義，漢譯佛經則另外寫為「 抴」。

（4）據此，古漢語文獻中「把」這個漢字有兩項語詞音義：一是表船獎率引的「 抴」，讀為餘制切，後文稱之為「抴去」；二是表用力拉扯義的「抴」（也 就是「拽」），讀為羊列切，後文稱之為「抴人」；兩者之間並無直接衍生 關係。

\section{2 掣}

《說文解字》未收「掣」字，但從古漢語文獻中可梳理出「掣」的早期語義用法，大 致可分為四類，下面分別說明。

\subsection{1＼cjkstart率制義}

上古漢語文獻中的「掣」多有其他相異的語詞寫法，如例（62）《周易》「其牛制」， 根據《經典釋文》所引述（例63）有兩種音義解釋：（1）鄭玄作 $「$ 㸷」，釋義為 $\ulcorner$ 牛角皆踊」，意指兩支牛角都豎立，音讀為「市制反」（禪母祭韻）；（2）《說 文解字》作「觢」，釋義為「角一俯一仰」，意指只有一支牛角向上豎立，音讀為 $\ulcorner 之 世 反 」 （$ 章母祭韻），其他作「㛃、觭」者語義上皆釋為一支牛角向上豎立；然 而, 段玉裁引《爾雅 - 釋獸》認為《說文》對「觢」之解釋「一角仰也」的「一」應 當作「二」（例64），乃因下文解釋「觭，角一俛一仰也」而導致此處筆誤，也就是 說段注認為「觢」意指兩支牛角都豎立, 《爾雅》、鄭玄、許慎的釋義均相同，但子 夏《易傳》、荀子引《易》則與之相異, 乃解釋為一角豎立。實際上無論兩角或一角

\footnotetext{
42 《廣韻》, 頁 378 。

43 《廣韻》, 頁 $377^{\circ}$
} 
向上豎立，都是因為有外力牽拉才會導致本當斜向伸展的牛角聳直豎立，此即《廣 韻》所釋「觢，牛角豎也」（時制切，禪母祭韻）。44據此來看，《周易》所謂「其 牛掣」者，本應為「其牛觢」或「其牛觭」，指的是牛角被外力牽拉而敢立的特殊狀 態，不完全等同於後起的 $「$ 掣」，但語義上有所關聯，因而後來被寫為「掣」; 孔穎 達《正義》（例62）從而以「掣」著重於率制動作中兩力相互作用的角度來解釋「其 牛掣」：主事者欲進，卻因牛被後頭受困的車子所牽制而停滯原地、無法前進。

（62）《周易.睽》六三：見韫曳，其牛制。

《正義》日：見輿曳其牛掣者，處睽之時，履非其位，以陰居陽，以柔乘 剛，志在上九，不與四合，二自應五，又與已乘。欲載，其輿被曳，失已所載 也; 欲進, 其牛被牽, 滯隔所在, 不能得進也, 故曰見舆曳其牛掣也。45

（63）《經典釋文・周易音義》：制，昌逝反。鄭作「㸷」，云牛角皆踊曰㸷。徐市 制反。《說文》作「觢」，之世反，云角一俯一仰。子夏作「栔」，傳云一角 仰也。苩作「觭」。劉本從《說文》, 解依鄭。46

（64）《說文解字》：觢，一角仰也。从角㓞聲。《易》日：「其牛觢」。

《段注》: 一當作二。《釋嘿》日：「角一俯一仰, 觭; 皆踊, 觢。」皆踊謂 二角皆豎也。蒙上文一俯一仰, 故曰皆。許一俯一仰之云在下文。故云二角,

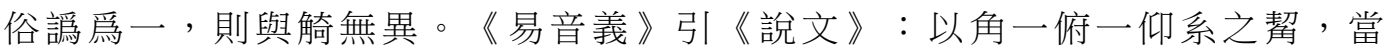
時筆誤耳。《睽》六三：其牛掣。鄭作恝, 云牛角皆踊曰恝。與《爾雅》、

《說文》同。子夏作契。荀作觭。虞作掣。皆以一俯一仰爲訓。與許、鄭不同 也。挈者, 如有掣曳然, 苗本當邪展而乃眥直也。 47

再如例（65）《詩經》「莫予茾蜂」，毛傳曰「茾蜂，摩曳也」，《爾雅》則作「甹 夆, 掣曳也」（例66），根據《爾雅注疏》，「茾㸘」、「蜂夆」、「摩掣」乃音義 皆同的異形語詞, 然則「摩曳」即「掣曳」, 意指從旁率挽拖拉而使之偏離正道。 《說文解字》未收「掣」但有「掱」，根據《經典釋文》解釋 $「$ 摩」為「引而縱之」 （例67）, 此即《說文》「掱」之釋義, 如例（68）, 段注非常精細地解釋「引縱」 所指向的兩力相互作用：一是某物理當趨向遠處, 但受外力牽制而滯留近處, 此為

$\ulcorner 引 」 ;$ 二是某物既受外力牽制而滯留近處, 一旦捨放外力遂使之移向遠處, 此為

$\ulcorner$ 縱」; 引而縱之便產生縮放交替的抽動狀態，如例（69）所述「䫑需目瘈」，即指 一般頭痛常見症狀：耳上䰅骨及眼睛之間發生不停緊縮又縱放的抽痛感。

（65）《毛詩·周頌·小毖》: 予其懲, 而毞後患; 莫予茾蜂, 自求辛蟄。

《疏》: 毛以為成王即政, 求助於群臣。告之云我其懲創於往時, 而謂管、蔡 誤已, 以為創艾, 故慎彼在後, 恐更有患難。汝等群臣, 莫復於我掣曳, 牽我 以入惡道。若其如是, 我必刑誅於汝, 是汝自求是辛苦毒督之害耳。48

44 《廣韻》, 頁 $377^{\circ}$

45 (魏) 王弼、韓康伯注, (唐) 孔穎達等正義：《周易正義》, 臺北：新文豐出版社, 2001 , 頁 $327-328$ 。

46 （唐）陸德明撰：《經典釋文》，上海：上海古籍出版社， $2013 ，$ 頁 101-102。

47 《說文解字注》, 頁 $187^{\circ}$

48 (漢) 毛公傳, (唐) 孔穎達等正義：《毛詩正義》，臺北：新文豐出版社，2001，頁 2051-2052。 
（66）《爾雅・釋訓》: 甹夆, 掣曳也

《疏》：釋曰：孫炎曰：謂相掣曳，入於惡也。郭云：謂率挽。《周頌・小 毖》嗣王求助也, 云「莫予茾蜂」。毛傳云：莽蜂, 摩曳也。鄭箋云：群臣小 人, 無敢我摩曳, 謂為譎詐註欺, 不可信也。然則制曳者從旁牽换之, 言是挽 離正道，使就邪僻。茾、甹，夆、蜂，制、麾音義同。49

（67）《經典釋文・爾雅音義》: 萝, 普經反; 夆, 孚逢反; 掣本或作摩, 同充世 反，《說文》云「引而縱之」。曳，餘世反。50

（68）《說文解字》：引縱曰挈。

《段注》: 《爾雅》《釋文》作「引而縱之曰痵。」引，開弓也。縱，緩也， 一曰舍也。按：引縱者, 謂宜遠而引之使近, 宜近而縱之使遠, 皆爲率掣也。

不必如《釋文》所據《爾雅》日：甹夆，掣戔也。俗字作撦、作扯，聲形皆異 矣。51

（69）《黃帝內經·靈樞·熱病》: 熱病頭痛, 顳需目㿇, 脈痛, 善衄, 厥熱病也, 取 之以第三鍼, 視有餘不足, 寒熱痔。52

相對於「引而縱之」的「症」，《說文解字》另外收錄了「瘛痤」（例70），段注說 明「瘛」即「掣」, 意指牽制緊縮, 而「瘲」即「縱」, 意指縱放伸展 ; 如例（71） 所述, 既牽制又縱放, 或緊縮或伸展, 抽動不止便是「疰疭」, 也就是今日所謂「抽 搐」。這樣說來, 「㿇」包含了牽制與捨放的引縱過程, 「疰」則僅指率制所導致的 緊縮狀態, 兩者語義略有廣狹差異。相應於「瘛」，古漢語文獻中「掣」的語義也僅 指向「宜遠而引之使近」的牽制動作，如例（72）「行善制節」意指走路時骨關節受 到牽制緊縮而不良於行，例（73）「心塹」意指心臟受到牽制而緊縮滯隔, 例（74）

「咽鳴制縮」意指說話吞吞吐吐，如受外力牽制緊縮而不敢完全吐實。

（70）《說文解字》：小兒瘛㾢, 病也。

《段注》: 《急就篇》亦云痖瘲。師古云：師今癇病。按：今小兒驚病 也。瘛之言掣也; 疭之言縱也。53

（71）《傷寒明理論》: 瘱者, 筋脈急也; 疭者, 筋脈緩也。急者則引而縮, 緩者則 縱而伸，或縮或伸，動而不止者，名曰瘛疭。俗謂之搐者是也。54

（72）《黃帝內經·靈樞·五邪》邪在肝, 則兩脅中痛, 寒中, 惡血在內, 行 善制節……取耳間青脈，以去其制。5

（73）《黃帝內經·素問·陰陽別論》一陽發病, 少氣善咳, 善泄; 其傳為心制, 其傳 為隔。56

（74）《抱朴子・袪惑》昔有古強者……揚州稽使君聞而試迎之於宜都。既至，而 咽鳴制縮, 似若所知實遠, 而未皆吐盡者。57

49 (晉) 郭璞注, (宋) 邢呙疏：《爾雅注疏》, 臺北：新文豐出版社, 2001, 頁 204。

50 《經典釋文》, 頁 1623 。

51 《說文解字注》, 頁 608 。

$5^{2}$ (漢) 《黃帝內經 : 靈樞》, 臺北：廣文書局, 1991年, 卷五, 頁6。

53 《說文解字注》, 頁 356 。

54 （宋）成無已撰：《傷寒明理論》, 北京：中華書局, 1985 , 頁 33 。

55 《黃帝內經: 靈樞》, 卷五, 頁4。

56 (唐) 王冰編次, (宋) 高保衡、林億校正, 吳潤秋整理：《素問》, 海 $\square$ : 海南國際出版中 心, 1996 , 頁 10 。

57 （晉）葛洪撰：《抱朴子》, 臺北：臺灣商務印書館, 1979, 頁116。 
據此，《說文》所釋「掱」、「應」語義略有差異，表率制義的「掣」與「疰」較為 相近，但三者應具有密切的音義發展關係。然則《爾雅》、毛傳、鄭箋的「摩曳/掣 曳」並不完全等同於「掱」; 根據注疏來看, 做為君王者理應處於正道向前邁進,

「摩曳/掣曳」乃指向群臣小人從旁率挽拖拉而使君王親近偏僻歪邪之路, 此僅相應於

$「$ 看」的第一層率制動作「某物理當趨向遠處，但受外力率制而滯留近處」。「掣」 表率制的動作語義另有諸多文獻例證，如例（75）「當道制頓人車馬」意指在路上牽 制住行進的車馬，例（76）「制其肘」意指率制手肘而使人無法自由書寫，例（77）

「牽制虜手」意指俘虜被敵方所牽制而無法返回家鄉，這裡受事賓語車馬、手肘、俘 虜均是受到外力反向牽制而無法自由行動，也是符應「某物理當趨向遠處，但受外力 率制而滯留近處」的動作語義。

（75）《史記·滑稽列傳》乳母家子孫奴從者橫暴長安中，當道制頓人車馬，奪人衣 服。58

（76）《孔子家語·屈節解》宓子戒其邑吏，令二史書，方書輙制其肘，書不善，則 從而怒之，二史患之，辭請歸魯。59

（77）《三國志·魏書·高貴鄉公髦》洮西之戰, 至取負敗, 將士死亡, 計以千數, 或 沒命戰場，冤魂不反，或牽制虜手，流離異域，吾深痛慗，為之悼心。60

總和以上討論，早期漢語文獻中「掣」的核心語義均為「反向拖拉而率制某物」，屬 於動作動詞，語法結構上受到率制的受事賓語可以置後（如：掣肘、掣節），也可以 置前（如：無敢我掣史、心掣），其中受事賓語置前者又與相對動作「宜近而縱之使 遠」的「縱」合言, 遂發展出「瘛疭」一詞表縮放交替的抽搐狀態。至於「掱」乃兼 表引而縱之的抽動狀態，語義上有所擴充，應屬牽制義的進一步發展。

\subsection{2 抽動義}

掣」以「反向拖拉而率制某物」為核心語義，被牽制的受事者往往具有與施力者相 反方向的反抗動力, 當施力大於抗力便是牽制緊縮, 一旦施力稍微䋧放, 抗力大於施 力, 受事者便會朝向原來行進方向伸展, 這兩種力量相互對抗的過程中很自然地呈現 或縮或伸的抽動狀態，此即「引縱曰瘛」，例如前例（69）「䫑需目瘛」，即指耳上 㰓骨及眼睛之間不停緊縮又鬆放的抽痛狀態。除了身體部位的抽動稱之為「瘛」，發 展出引縱抽動義的「掣」也用來描述閃電的急速隱現，彷若有外力迅速拉出電光又放 開電光，如例（78）「風馳電掣」意指風快速流動、閃電急速抽動，例（79）以「掣 電」對「流星」，可見這裡「㲛」也是急速抽動的狀態。

（78）《六韜・龍韜・王翼》奮威四人：主擇才力, 論兵革, 風馳電掣, 不知所由。61

（79）《敦煌變文集新書・漢將王陵變》人如制電，馬似流星，不經旬日，便到漢 國。62

58 《史記附札記》，頁 3204 。

59 （三國）王肅注：《孔子家語》, 臺北：臺灣中華書局，1981，卷八，頁8。

60 （晉）陳壽撰，（南朝宋）裴松之注《三國志》，臺北：鼎文書局，1979，頁133-134。

61 （周）呂望撰：《六塪》, 臺北：廣文書局，1991, 頁5。

62 《敦煌變文集新書》, 頁 884 。 
3.2.3用力拉扯義

東漢以後的漢語文獻中，「掣」出現用力拉扯而使之斷裂或移動的語義用法，如例

（80）「堙絕」、（81）「塹衣」、（83）「掣毀」均指用力扯裂衣物，例（86）

$\ulcorner$ 制窗紙一片」意指用力扯下一片窗紙; 而例（ $82 ） 「$ 拖制屍出」意指用力把屍體拖 拉出來，例（84）「搖制」意指用力拖拉牛隻而使之前進，例（85）「制其筆」意指 用力拉扯、欲取其筆。本文認為「㨻」的用力拉扯義乃衍生自牽制義：「掣其肘」一 類動作事件中, 被率制的受事者往往具有與施力者相反方向的反抗動力, 但因施力大 於抗力, 受事者遂受牽制而無法自由行動; 當受事者不具相反方向的反抗動力, 只有 固著原地的重力，如例（80）-（86）的衣物、窗紙、屍體、牛隻、毛筆，施力者的用 力拉引很容易促使不具反抗力的受事者發生斷裂或移動, 便衍生出「掣絕衣裾」或

「拖掣屍出」一類用力扯斷、拉動的語義。

（80）《搜神記・營陵道人》當出戶時，忽掩其衣裾戶間，制絕而去。63

（81）《大藏經 . 生經 ·佛說比丘尼現變經》候比丘尼, 適脫衣被, 入水洗浴。尋 前制衣, 持著遠處, 欲率犯之。64

（82）《大藏經・經律異相》見死者甚多。諸飛鳥走狩爭食其肉。或就土中拖制屍 出。65

（83）《大藏經・佛本行集經》以手指爪, 篗裂四支, 身體皮肉。所著衣服, 皆 悉制毀。66

（84）《大藏經・佛本行集經》牛若行遲，時時搖制，日長天熱，喘嚇汗流。人牛並 皆困乏飢渴。67

（85）《晉書・王獻之傳》（獻之）七八歲時學書, 羲之密從後制其筆不得, 歎曰: $\ulcorner$ 此兒後當復有大名。」68

（86）《朱子語類》其婦慧甚, 臨赴法時, 遂制窗紙一片, 即搯成一「番」字, 使人 送與其夫云云。69

\subsection{4 抽取義}

到了宋明以後的漢語文獻中, 「幋」又衍生出表示抽取的動作語義，如例（ $87 ）-$ （90）絕大多數都指向抽取武器, 此相異於上述用力拉扯而使之斷裂或移動的語義, 且與原來的率制義更形遙遠。仔細來看, 受事者不僅不具相反方向的反抗動力, 且乃 屬於施力者的隨身器物, 施力者不需用力拉引, 只需抽拿而使該器物移動, 或是由隱 藏而顯現。

\footnotetext{
63 《搜神記》，頁 30 。

64 (晉) 釋法護譯: 《生經》, 收錄於《中華大藏經》第三十四冊, 上海：中華書局, 1988 , 卷四, 頁 781 。

65 （梁）釋寶唱集：《經律異相》, 收錄於《中華大藏經》第五十三冊, 上海：中華書局, 1992 , 卷三 十四, 頁 164 。

66 ( 隋) 闍那崛多譯：《佛本行集經》, 收錄於《中華大藏經》第三十五冊, 上海：中華書局, 1989 , 卷十七, 頁 726 。

67 《佛本行集經》, 卷十二, 頁 $677^{\circ}$

68 (唐) 房玄齡等撰 : 《晉書》, 臺北：鼎文書局, 1979, 頁 2105 。

69 (宋) 黎靖德編, 王星賢點校：《朱子語類》, 北京：中華書局, 1986 , 卷一百三十, 頁 3119 。
} 
（87）《水澈傳・第六回》智深又鬥了十合, 鬥他兩個不過, 制了禪杖便走。70

（88）《水湤傳・第七回》那漢䬂的把那口刀制將出來, 明晃晃的奪人眼目。71

（89）《西遊記・第五回》大聖即現本相，耳朵內掣出金䈨棒，幌一幌，碗來粗細。72

（90）《西遊記・第六回》等我制拳，先搗牕櫺，後踢門扇。73

表 $5 \quad\ulcorner$ 掣」的語義發展演變

\begin{tabular}{|c|c|c|c|c|c|c|}
\hline \multicolumn{2}{|c|}{ 掣 } & \multicolumn{3}{|c|}{ 受事者 } & 力量大小 & 施力者 \\
\hline 牽制義 & 掣其肘 & [+反抗力] & [-移動] & & [抗力 $\leqq$ 施力] & [+控制] \\
\hline 抽動義 & 目掱/電掣 & [+反抗力] & [ \pm 移動 $]$ & & [抗力 $\geqq$ 施力] & [ \pm 控制] \\
\hline 用力拉扯義 & 尋前掣衣 & $\begin{array}{l}\text { [ } \pm \text { 反抗力 } \\
\text { (固著重力 ) }\end{array}$ & [+移動/岰裂] & [-施力者所有] & [抗力 < 施力 ] & [-控制] \\
\hline 抽取義 & 掣了禪杖 & [-反抗力] & [+由隱而現] & [+施力者所有] & [抗力 < 施力] & [-控制] \\
\hline
\end{tabular}

總合以上討論「掣」的語義用法之發展演變如表 5 ：

（1）「掣」原為率制之義，指向「宜遠而引之使近」的率制動作，其所率制的受事 者往往具有反向的抗力，如例（75）-（77）的車馬、手肘、俘虜，此時施力者 力量大於或等於受事抗力, 因此受事者被牽制而無法朝向原來行進方向移動, 此種動作情境下，施力者具有顯著的控制性。

（2）「掣」在「反向拖拉而牽制某物」的核心語義下，受到牽制的受事賓語可以置 後（如：掣肘、掣節），也可以置前（如：無敢我掣曳、心掣），其中受事賓 語置前者又與相對動作「宜近而縱之使遠」的「縱」合言，遂發展出「疰瘲」 一詞表縮放交替的抽搐狀態；進一步以「掱」兼表引而縱之的連續動作。其所 引縱的受事者同樣具有反向的抗力, 施力者先牽制、再縱放, 並且連續重複這 兩項動作，兩力由相互抗衡轉為抗力大於施力、又轉為抗衡，受事者在受制無 法移動與可自由移動之間交替，便形成抽動狀態，此種動作情境下，施力者既 有控制性又非完全控制。

（3）本文認為「掣」的用力拉扯義亦衍生自牽制義，原來牽制的受事賓語多具有 反向的抗力，東漢以後「掣」的受事賓語擴展至不具有反向動力、但有固著原 地之重力的某物, 如例（80）-（86）的衣物、窗紙、屍體、牛隻、毛筆，施 力者的用力拉制也易促使受事者發生斷裂或移動，因而語義上由率制義轉為用 力拉扯義。此時施力者的力量遠大過於受事者的重力，這裡 [-控制]非指施力者

\footnotetext{
70 （明）施耐庵撰：《水游傳》, 臺北：桂冠圖書, 1992 , 頁 92 。

71 《水滸傳》, 頁 110 。

72 (明) 吳承恩撰, 徐少知校, 朱制、周中明注 : 《西遊記校注》, 臺北 : 里仁書局, ${ }_{1996}$, 頁 91 。

73 《西遊記校注》, 頁 115 。
} 
無法控制，而是受事賓語不具反向動力，故不具有「反向控制某物」的動作情 境。

（4）宋明以後「掣」的受事賓語又擴展至完全不具有反向抗力、且屬於施力者所擁 有的器物，如例 $(87)-(90)$ 的禪杖、刀、金箍棒、拳頭，施力者不需用力拉 扯，而是抽拿以使該器物移動，特別是由隱藏而顯現（刀、金箍棒、拳頭）， 語義上由用力拉扯義又轉為抽取義。

（5）音讀方面，《廣韻》記錄「瘈」為尺制切，74「掣」則有兩讀：一是尺制切 （昌母祭韻去聲），釋義為「掣曳也」，75下文稱之為「掣去」；二是昌列切 （昌母薛韻入聲），釋義為「挽也」，76下文稱之為「掣人」。前述上古漢語 文獻中的「掣」經常與「曳」並列出現，音讀只見去聲一讀，這樣看來東漢以 前表率制義、抽動義的「掣/掱」只有去聲一讀；東漢以後，「掣」發展出用 力拉扯義，語義上與「挽」相近，音讀上則出現入聲讀法。

\section{3「抴/电」與「掣」的源流發展關係}

上古漢語文獻中「掣去」經常與「曳」並列出現，如前例（62）《周易》「見輿曳， 其牛掣」，「輿曳」乃指車子後邊被拖住而無法承載，「其牛掣」則一指牛角被外力 率拉而聳立的特殊狀態, 另一指牛被後頭受困的車子所率制而停滞原地、無法前進; 再如例（66）《爾雅》「甹夆，掣曳也」，意指群臣小人從旁率挽拖拉、驅使君王偏 表 $6 「$ 把/曳 $V S$ 掣」的語義發展比較

\begin{tabular}{|c|c|c|c|c|c|c|}
\hline \multicolumn{2}{|c|}{ 抴/电VS掣 } & \multicolumn{3}{|c|}{ 受事者 } & 力量大小 & 施力者 \\
\hline 牽引義 & 抴舟 & [-反抗力] & [+移動] & $\begin{array}{l}\text { [-施力者所 } \\
\text { 有] }\end{array}$ & [抗力<施力] & [土隨帶受事] \\
\hline 拖曳後物義 & 曳尾 & [-反抗力] & [+移動] & $\begin{array}{l}{[+ \text { 施力者所 }} \\
\text { 有 }]\end{array}$ & [抗力<施力 ] & [+隨帶受事 $]$ \\
\hline 用力拉扯義 & $\begin{array}{l}\text { 抴裂我衣 } \\
\square \text { 拽純衣 }\end{array}$ & $\begin{array}{l}\text { [ } \text { 反抗力 }] \\
\text { (固著重力) }\end{array}$ & $\begin{array}{l}\text { [+移動/糹 } \\
\text { 裂 }]\end{array}$ & $\begin{array}{l}\text { [-施力者所 } \\
\text { 有] }\end{array}$ & [抗力<施力] & [-隨帶受事] \\
\hline 牽制義 & 掣其肘 & [+反抗力] & [-移動] & & $\begin{array}{l}{[\text { 抗力 } \leqq \text { 施 }} \\
\text { 力 ] }\end{array}$ & [+控制] \\
\hline 抽動義 & 目瘭/電掣 & [+反抗力] & [土移動 $]$ & & $\begin{array}{l}{[\text { 抗力 } \geqq \text { 施 }} \\
\text { 力] }\end{array}$ & [控制] \\
\hline 用力拉扯義 & 尋前掣衣 & $\begin{array}{l}\text { [坂抗力 }] \\
\text { (固著重力) }\end{array}$ & [+移動/斷裂 $]$ & $\begin{array}{l}\text { [-施力者所 } \\
\text { 有] }\end{array}$ & [抗力<施力] & [-控制] \\
\hline
\end{tabular}

$\begin{array}{ll}74 & \text { 《廣韻》, 頁 } 377^{\circ} \\ 75 & \text { 《廣韻》, } \\ 76 & \text { 《頁 } 377^{\circ} \\ \end{array}$


離正道而親近偏僻歪邪之路；由此可見「掣去」與「曳」十分相近，共同具有「拉 引」動作的核心語義。然而，如前兩小節的分析與討論（表6）：「曳」本為拖曳後 物義, 其受事賓語多為施力者所擁有的一小部分, 不具有反向抗力, 因此施力者拉引 受事者乃隨帶於身後, 此即拖曳之義; 相異於此, 「掣去」本為荤制義, 其受事賓語 多具有反向抗力, 施力者力量僅略大於受事抗力或兩力相當, 因此施力者拉引受事者 乃加以控制而使之不移動，此即率制之義。據此，「掣去」與「曳」雖共同具有「拉 引」動作的核心語義, 但其受事賓語特性相異, 從而兩者詞義並不完全一致。但是到 了東漢以後, 兩者又都發展出用力拉扯的相同詞義：「曳」由拖曳後物到拖拉外物、 再到拉扯外物而欲使之斷裂（抴人/拽）; 「掣去」由反向率制外物到拉扯外物而欲 使之斷裂（掣人）；漢譯佛經中出現「掣、抴」同義（例54、84）、「掣拽」並列（例 $61)$ 的例證。

根據上述分析比較，「掣去」與「曳」原來詞義側重處不同，但兩者共同具有 $\ulcorner$ 拉引」動作的核心語義, 並且後來有相同趨向的發展, 是否可能為來自同一詞源的 同族語詞關係呢？從語義上來看，如前所述，「把」」、「曳」兩詞皆從「「」杽乳 衍生, 乃由橫向拉引的本義分別發展出「牽引」與「拖曳」兩種引申義, 兩者最大差 別在於受事賓語是否歸屬施力者所擁有; 若進一步從受事賓語是否具有與施力者拉引 方向相反的前進抗力來看，「宜遠而引之使近」的「掣去」之牽制義極可能同樣源於

$\ulcorner\Gamma 」$ 拉引動作的延伸。

表7 「抴/曳VS揱」的音讀衍生脈絡

\begin{tabular}{|c|c|c|c|c|c|}
\hline \multirow[t]{2}{*}{$\begin{array}{l}\text { 厂 } \\
\text { (橫向拉引) } \\
\text { 【餘制切】 } \\
{ }^{* *} \operatorname{lad}\end{array}$} & 拖电 & $\rightarrow$ & $\begin{array}{l}\text { 曳：拖曳後物 } \\
\text { 【餘制切】 }{ }^{* *} \mathrm{lad}\end{array}$ & $\rightarrow$ & $\begin{array}{c}\text { 曳：用力拖拉 } \\
\text { 【餘制切】**lad > *jiäi } \\
\downarrow \\
\text { 抴 人/拽：用力拉扯 } \\
\text { 【羊列切】**lat > *jiät }\end{array}$ \\
\hline & 牽引 & $\begin{array}{l}\rightarrow \\
\rightarrow\end{array}$ & $\begin{array}{l}\text { 抴去: 船獎率引 } \\
\text { 【餘制切】**lad>*jiäi } \\
\text { 泄/洩：漏泄 } \\
\text { 【私列切】**slat>*sjät }\end{array}$ & $\rightarrow$ & $\begin{array}{l}\text { 泄：排泄穢物 } \\
\text { 【私列切】 }{ }^{* *} \text { slat>*sjät }\end{array}$ \\
\hline$?$ & 牽制 & $\rightarrow$ & 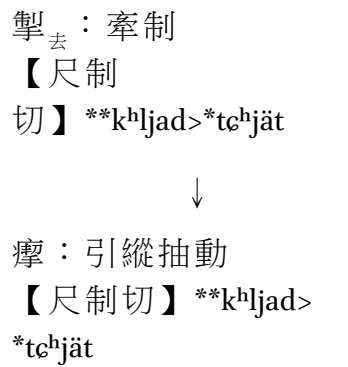 & $\rightarrow$ & $\begin{array}{l}\text { 掣人：用力拉扯 } \\
\text { 【昌列切】 }{ }^{* *} \mathrm{k}^{\mathrm{h}} \mathrm{ljat}> \\
{ }^{*} \mathrm{t}^{\mathrm{h}} \mathrm{jät}\end{array}$ \\
\hline
\end{tabular}


然而, 歷史音讀上的解釋較有疑慮, 如表7所示, 上古擬音主要根據李方桂（1998） 以及龔煌城（2004）對上古聲母擬音的若干修訂, 這些語詞的上古韻讀均來自祭部, 但分有去聲、入聲兩類：（1）「抴去」、「曳」兩詞皆從「「」斈乳衍生，音讀上皆 為以母祭部去聲, 東漢以後「曳」因詞義演變而出現入聲讀法, 字形上另外寫為

$\ulcorner$ 把、/拽」；另有同樣從「「」杽乳衍生的「泄」（參見4.3節討論），屬心母祭部入 聲, 聲母類別上同屬舌齒音大類；（2）相對於此，「掣去」為古昌母祭部去聲，東漢 以後因詞義演變也出現入聲讀法, 其聲母類別在中古雖與 $「$ 把、/拽/泄」同屬舌齒音大 類, 但根據 3.2 節所述 $「$ 掣去」與 $「$ 掱、應」的緊密關係, 「掣去」的上古音應來自牙喉 一類, 其與來自舌尖聲類的「把去/曳/泄」在歷史音讀上尚未能充分論證同出一源, 有 待未來繼續深入考證。77

此外, 需要特別說明的是, 「曳」與「掣去」在東漢以後同樣發展出用力拉扯的 動作語義, 而且隨著語義杽生, 兩者都出現入聲讀法（抴、/拽、掣人）。根據梅祖麟 ( $2000 \mathrm{~b})$ 的討論, 四聲別義為古漢語構詞的一種方式, 尤其去入別義最為常見, 分為 三種類型：（A）以入聲為名詞、以去聲為動詞，例如「惡（名詞）-惡去（動詞）」;

（B）另有相對一型乃以人聲為動詞、以去聲為名詞，例如「度人（動詞）-度去（名 詞）」。梅文認為（B）以去聲為名詞的時間層次早於（A）以去聲為動詞，（B）為 承繼共同漢藏語的構詞方法, 而 (A) 為晚期類比的產物; 此外還有另一型（C）乃以 非去聲為內向動詞、以去聲為外向動詞，例如「買上（內向動詞）-賣去（外向動詞）」。 然而, 梅文所提出的四聲別義三種類型, 主要乃為區別同一語詞在語句中不同的語法 功能（名詞或動詞，內向動詞或外向動詞），而非同族語詞的語義杽乳衍生。楊秀芳 （2017）詳細區別語詞的杽生與派生：所謂杽生乃以某詞為詞根, 經過詞義聯想引申 而杽生新詞; 而派生則是來源詞在原來用法之外擴大語法功能及詞義表達範圍，因而 出現在不同句法位置, 採取不同認知角度, 因此別出為不同的詞性或詞義。據此來 看, 本文所討論「把/曳」與「掣」的語義發展應屬語義玄生脈絡, 語音或變或不變, 雖然無法運用梅文的去聲別義類型來加以說明，但明顯反映由原來詞根的去聲讀法逐 漸發展出入聲讀法的共同變化趨向。

\section{4 「把/曳/掣/泄」在閩語的演變發展}

本文第二節探討閩南、閩東若干與「抴/曳/掣」相關之語詞的語義用法及其發展演 變, 第三節彙整、析論古漢語文獻中「抴/曳/掣」的語義用法及其音義衍生脈絡。我 們認為第二節所探討的閩語若干語詞與漢語詞「抴/曳/掣」之間具有密切的同源關 係, 以下分別析論其音義對應關係以及閩語內部的個別發展, 並論及另一同族語詞 $\ulcorner$ 泄」。

77 不過, 做為「把去」、「曳」、「泄」等語詞起源的「「」為以母祭部去聲, 上古音構擬為**lad, 上 古以母除了與舌齒聲類往來, 也經常與牙喉聲類往來, 因此也可能有另一種解釋方案 : 參照 $「$ 容 $(* \operatorname{lug})$ 、頌 $(* \operatorname{lju}) 」$ 的音讀關係, 表拉引義的「厂」（**lad）另有邪母音讀（**ljad），閩南將 $\left\ulcorner\right.$ 把 $/$ 曳」讀為 $\mathrm{ts}^{\mathrm{h}} \mathrm{ua}$ 可做為方言例證, 後來因受事者具反向抗力而衍生牽制義者, 音讀上為了辨別 語義而增衍詞首牙喉音 $\left(* * \mathrm{k}^{\mathrm{h}}\right.$ - $\left.\mathrm{ljad}\right)$, 中古音遂演變為昌母祭韻, 但是這個解釋方案目前缺乏充足的 音韻證據來證明牙喉音詞首的增衍規則。 


\section{1 閩南方言表引領義的 $\mathrm{ts}^{\mathrm{h}} \mathrm{ua7}$ 聯繫為「抴 ${ }_{\text {去 }} /$ 曳」}

本文認為閩南方言表引領義、討娶義的 $\mathrm{ts}^{\mathrm{h}} \mathrm{ua} 7$ 應聯繫為漢語詞表率引、拖曳義的 「把去曳」，下面分語義、歷史音韻兩方面進行說明。

（1）從語義對應關係來看：抴、曳的率引義與拖曳義，恰與閩南方言 $\mathrm{ts}^{\mathrm{h}} \mathrm{ua}$ 的帶 領義及隨帶義相應; 而閩南方言表引領義的 $t s^{\mathrm{h}} \mathrm{ua}$ 又個別發展出討娶、照顧、 引致等特殊用法。然而，語法結構對應上稍有不足，閩南方言 $\mathrm{ts} \mathrm{s}^{\mathrm{h}} \mathrm{ua}$ 出現的 句式多為「主語 $+\mathrm{ts}^{\mathrm{h}} \mathrm{ua} 7+$ 賓語 + 趨向詞+處所詞（+動詞組）」; 而表牽引義的 $\ulcorner$ 抴去」缺乏動詞用法的例證，表拖曳義的「曳」雖為動作動詞可搭配受事 賓語, 但尚未出現後接趨向補語以明確表示帶領賓語移動, 直到表拖拉義的 $\ulcorner$ 曳」出現例（50）「走卒前曳下堂皇」、例（52）「曳遐墜地」一類句式, 語法結構方與 $\mathrm{ts}^{\mathrm{h}} \mathrm{ua}$ 相近, 但語義上又稍有差異, $\mathrm{ts}^{\mathrm{h}} \mathrm{ua}$ 並不具拖拉義而是率引 之義。據此來看, 閩南方言 $\mathrm{ts}^{\mathrm{h}} \mathrm{ua} 7$ 在語義上接近表率引義的「把去」，在語法表 現上則接近「曳」，著眼於「把去、曳」的同族語詞關係，tsh ${ }^{\mathrm{h}} \mathrm{u}$ 可以合理與之 聯繫，同樣源於拉引的核心語義，發展出牽引之義，但語法表現上乃做為動詞 使用。

（2）從歷史音韻規則來看：把去、曳皆屬古以母祭部去聲, 中古進入祭韻。閩語聲 母有反映古邪以同源的古老層次，如表8所示，78 古邪以二母同讀有三項音讀 對應規則：（甲）為閩南、閩東同讀為 s-，例如「鹽蠅翼趐寺」；（乙）為閩 南讀為ts-，閩東讀為s-，例如「簷癢謝松」;（丙）為閩南、閩東同讀為 $\mathrm{ts}^{\mathrm{h}}$ - , 古邪母語詞如 $「$ 席飼」，古以母語詞如閩南指稱讓風吹揚的 $\left\ulcorner\mathrm{ts}^{\mathrm{h}} \mathrm{iu}\right.$ 出 $\lrcorner$ 。據此 來看，古以母語詞「把去/曳」在閩南方言聲母音讀為 $\mathrm{ts}^{\mathrm{h}}$ ，乃符合（丙）類規 則。而閩語韻母有反映古歌祭元相應的古老層次, 如表 9 所示, 古祭部語詞在 閩東讀為ia/iak, 閩南則是非舌根聲母條件下讀為ua/ua? 、舌根聲母條件下讀為 $\mathrm{ia} / \mathrm{ia}$ 。據此來看，古祭部去聲語詞「把去/曳」在閩南方言韻讀為-ua，亦符合歷 史音變規則。而古以母屬濁聲母, 濁聲母去聲在今閩南方言讀為陽去調亦合於 規則。也就是說, 表率引、拖曳義的 $\left\ulcorner\right.$ 把 ${ }_{\text {去}}$ 曳 」在今日閩南方言讀為 $\mathrm{ts}^{\mathrm{h}} \mathrm{ua} 7$, 聲、韻、調完全合於歷史演變規則。

\section{2 閩南、閩東表拉扯義的 $\mathrm{ts}^{\mathrm{h}} \mathrm{ua} 4$ / $\mathrm{ts}^{\mathrm{h}}$ iak4 聯繫為「掣入}

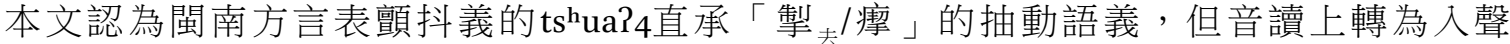
音讀, 而閩南、閩東方言相應為表拉扯義、扯動義的 $\mathrm{ts}^{\mathrm{h}} \mathrm{uaP}_{4} / \mathrm{ts}^{\mathrm{h}} \mathrm{iak} 4$, 則聯繫為表用力 拉扯義的「掣人」。下面也分語義、歷史音韻兩方面進行說明。

（1）從語義對應關係來看：閩南方言表顫抖義的 $\mathrm{ts}^{\mathrm{h}} \mathrm{ua} 4$ 與 $「$ 掣去/掱」的引縱抽動義 完全相合，此應由「掣去」的牽制本義擴展而來，語法表現上多為狀態動詞用 法；而閩南方言、閩東方言表拉扯義的 $\mathrm{ts}^{\mathrm{h}} \mathrm{ua}$ 4/ $\mathrm{ts}{ }^{\mathrm{h}} \mathrm{iak} 4$ 則是緊密相應於東漢以後 $\left\ulcorner\right.$ 掣人」表示用力拉扯而使之斷裂或分離的詞義，但閩東方言 $\mathrm{ts}^{\mathrm{h}}$ iak4又個別發展

78 本文表 8-9所用來比較的閩南、閩東方言點語料來源如下：閩南方言-泉州（林連通1993）、漳州（馬 重奇1993）、澄海（林倫倫1996）；閩東方言-福清（馮愛珍1993）、古田（《古田縣志》1997）、柘榮 (《柘榮縣志》1995)。 
表 8 古邪以母同源在閩南、閩東的音讀對應關係

\begin{tabular}{|c|c|c|c|c|c|c|c|c|}
\hline \multirow[t]{2}{*}{ 例字 } & \multirow[t]{2}{*}{ 中古 } & \multirow[t]{2}{*}{ 聲類 } & \multicolumn{3}{|c|}{ 閩南方言 } & \multicolumn{3}{|c|}{ 閩東方言 } \\
\hline & & & 泉州 & 漳州 & 澄海 & 福清 & 古田 & 柘榮 \\
\hline \multicolumn{3}{|l|}{ （甲） } & $\mathrm{s}$ & $\mathrm{s}$ & $\mathrm{s}$ & $\mathrm{s}$ & $\mathrm{s}$ & $\mathrm{s}$ \\
\hline 鹽名詞 & 3咸-鹽 & 喻四 & sĩ5 & sĩ5 & & sien3 & siey3 & $\operatorname{siej} 3$ \\
\hline 鹽 $79{ }$ 動詞 & 3咸-鹽 & 喻四 & sĩ3 & sĩ7 & & sien3 & sien3 & siey3 \\
\hline 蠅 & 3 曾-蒸 & 喻四 & $\sin 5$ & $\sin 5$ & $\sin 5$ & $\sin 5$ & $\sin 5$ & \\
\hline 翼翅 & 3 曾-蒸 & 喻四 & sit8 & sit8 & & si?8 & sik8 & siek8 \\
\hline 寺 & 3止-之 & 邪 & si3 & si5 & ( $\left.\mathrm{zi}_{7}\right)$ & se 7 & si 7 & \\
\hline \multicolumn{3}{|l|}{ (乙) } & ts & ts & ts & $\mathrm{s}$ & $\mathrm{s}$ & $\mathrm{s}$ \\
\hline 簷檐 & 3咸-鹽 & 喻四 & tsĩ5 & tsĩ5 & $\left(\operatorname{siam}_{5}\right)$ & siej5 & sien5 & \\
\hline 癢 & 3宕-陽 & 喻四 & tsiũ 6 & tsiõ7 & tsiẽ 6 & syoy7 & syøy7 & syø!7 \\
\hline 謝姓 & 3假-麻 & 邪 & & tsia7 & tsia7 & sia7 & sia7 & sia7 \\
\hline 松 & 3 通-鍾 & 邪 & $\operatorname{tsin} 5$ & $\operatorname{tsin} 5$ & （ts $\left.{ }^{\mathrm{h}} \mathrm{y}_{5}\right)$ & syy5 & syy5 & suy5 \\
\hline \multicolumn{3}{|l|}{ （丙） } & ts $^{h}$ & $\mathrm{ts}^{\mathrm{h}}$ & ts $^{h}$ & $\operatorname{ts}^{h}$ & ts $^{h}$ & ts $^{h}$ \\
\hline 揚揚風 & 3宕-陽 & 喻四 & $\mathrm{ts}^{\mathrm{h}} \mathrm{iũ} 5$ & $\operatorname{ts}^{\mathrm{h}}$ iõ 5 & tsh $^{\mathrm{h}}$ iẽ 5 & & & \\
\hline 席 白讀 $^{2}$ & 3梗-清 & 邪 & $\mathrm{ts}^{\mathrm{h}}$ io?8 & ts $^{\text {hio? }}$ & ts $^{\text {hie? }} 8$ & ts $^{\text {hyol }}$ & tsh $^{\text {yø? }}$ & ts $^{\text {hyø?8 }}$ \\
\hline 飼镮養 & 3止-之 & 邪 & $\operatorname{ts}^{\mathrm{h}} \mathrm{i}$ & ts $^{\text {hi }}{ }_{7}$ & ts $^{\mathrm{h}} \mathrm{i}_{7}$ & ts $^{\mathrm{h}} \mathrm{e} 3$ & $\operatorname{ts}^{h_{1}}$ & $\operatorname{ts}^{h_{i 3}}$ \\
\hline
\end{tabular}

出拉傷義，此乃由主動拉扯的動作動詞轉為表示腰部或筋絡因受力拉扯而受傷 的狀態動詞，恰與閩南方言「挽（ban2）」同樣由用力拉扯動作轉為表示筋絡 受力拉扯而受傷的語義、語法發展平行相應。

79 閩南方言指稱「醃」為 $s i 23 / 7$, 閩東方言則讀為siej3, 該語詞可以合理聯繫為去聲讀的「鹽」, 說明如 下：《廣韻》收錄「鹽」有二音讀, 一為余廉切（中古以母 3 等鹽韻平聲），引《說文》釋義「歲

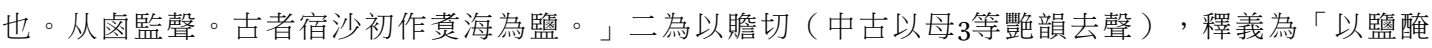
也」（《廣韻》，頁225、443）。古漢語文獻中「鹽」有做為以鹽醃製食物動作語義者, 如《禮記 內則》「屑桂與薑, 以灑諸上而鹽之, 乾而食之」（《禮記注疏》，頁1323）。而歷史音韻演變規則 方面, 古以母在閩語有讀為 s-的演變規則, 如 $「$ 蠅」讀為 $\sin 5 / \sin 5$ 、「翼」讀為 $s i t 8 / \operatorname{sik} 8$; 咸攝 $3 、 4$ 等 韻有讀為-1//-ien的演變規則, 如「染」讀為nĩ2/nien2、「簷（檐）」讀為 tsĩ5/sien5、「添」讀為 $\mathrm{t}^{\mathrm{h}} \mathrm{n} 1 / \mathrm{t}^{\mathrm{h}} \mathrm{iej1}$; 次濁去聲在閩南漳州歸讀陽去調, 泉州箇讀調不分陰陽去, 閩東方言有若干濁母去聲歸讀陰去調

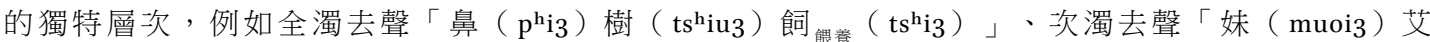
（ nia3）面（min3）」。據此, 閩南sĩ3/7、閩東 $\operatorname{sien3}$, 與漢語詞 $「$ 鹽去擎」在語義用法及歷史音韻上均 能密切相應, 應為同源語詞。 


\begin{tabular}{|c|c|c|c|c|c|c|c|c|c|}
\hline 例字 & 上古 & 中古 & 聲類 & 泉州 & 漳州 & 澄海 & 福清 & 古田 & 柘榮 \\
\hline & & & & $\begin{array}{l}\text { iã/uã } \\
\text { ia?/ua? }\end{array}$ & $\begin{array}{l}\text { iã/uã } \\
\text { ia?/ua? }\end{array}$ & $\begin{array}{l}\text { iã/uã } \\
\text { ia?/ua? }\end{array}$ & $\begin{array}{l}\text { iay } \\
\text { ia? }\end{array}$ & $\begin{array}{l}\text { iay } \\
\text { iak }\end{array}$ & $\begin{array}{l}\text { iay } \\
\text { iak }\end{array}$ \\
\hline 獺 80 & 祭 & 1山-寒 & $\mathrm{T} 1$ & $\mathrm{t}^{\mathrm{h}} \mathrm{uaP}_{4}$ & $\mathrm{t}^{\mathrm{h}} \mathrm{ua} 4$ & $\mathrm{t}^{\mathrm{h}} \mathrm{ua} 4$ & $\mathrm{t}^{\mathrm{h}} \mathrm{ia}{ }_{4}$ & $\mathrm{t}^{\mathrm{h}} \mathrm{iak} 4$ & $\mathrm{t}^{\mathrm{h}} \mathrm{iak} 4$ \\
\hline 熱 & 祭 & 3山-仙 & 日 & lua?8 & dzua?8 & zua?8 & & & \\
\hline 舌 ${ }_{\text {白讀 }}$ & 祭 & 3山 -仙 & $\mathrm{TS}_{3}$ & & & & & siak8 & \\
\hline 揭 81 & 祭 & 3山-元 & $\mathrm{K}$ & & gia?8 & kia24 $_{4}$ & kia?8 & kiak8 & \\
\hline 線 & 元 & 3山-仙 & $\mathrm{TS} 1$ & suã3 & suã3 & suã3 & sian3 & sian3 & sian3 \\
\hline 癬 82 白讀 & 元 & 3山-仙 & TS1 & ts $^{\mathrm{h}} \mathrm{uã2}$ & ts $^{\mathrm{h}} \mathrm{uã2}$ & & $\mathrm{ts}^{\mathrm{h}}$ ian 2 & ts $^{\text {hiay2 }}$ & \\
\hline 䱺 83 白讀 & 元 & 3山-仙 & $\mathrm{TS}_{3}$ & & & ts ${ }^{\mathrm{h}} \mathrm{ua} 6$ & $\mathrm{ts}^{\mathrm{h}}{ }_{\mathrm{ian}} 7$ & tshian $^{\mathrm{h}}$ & tshian${ }^{2}$ \\
\hline 健 & 元 & 3山-元 & $\mathrm{K}$ & kiã6 & kiã7 & kiã6 & kiay7 & kiay7 & \\
\hline \multirow[t]{2}{*}{ 燃白讀 } & 元 & 3山-仙 & 日 & hiã5 & hiã5 & hiã5 & & & niay5 \\
\hline & & & & ia/ua & ia/ua & ia/ua & ia & ie & ia \\
\hline 誓 $84_{\text {咒誓 }}$ & 祭 & 3蟹-祭 & $\mathrm{TS}_{3}$ & tsua3 & tsua7 & & $\left(\operatorname{sie}_{7}\right)$ & $\left(\operatorname{sie}_{7}\right)$ & $\left(\operatorname{sie}_{7}\right)$ \\
\hline 逝趟 & 祭 & 3蟹-祭 & $\mathrm{TS}_{3}$ & tsua3 & tsua7 & tsua7 & $\left(\operatorname{sie}_{7}\right)$ & & $\left(\operatorname{sie}_{7}\right)$ \\
\hline 艾 & 祭 & 1蟹-泰 & $\mathrm{K}$ & hia3 & hia7 & hia7 & yia3 & yia3 & yia3 \\
\hline 蛇 & 歌 & 3假-麻 & $\mathrm{TS}_{3}$ & tsua5 & tsuas & tsuas & sia5 & sies $_{5}$ & sia5 \\
\hline 我鳥 & 歌 & 1果-歌 & K & gia5 & & & yia5 & & yia5 \\
\hline 徛站立 & 歌 & 3止-支 & $\mathrm{K}$ & $\left(\mathrm{k}^{\mathrm{h}} \mathrm{a} 6\right)$ & $\mathrm{k}^{\mathrm{h}} \mathrm{ia}_{7}$ & $\mathrm{k}^{\mathrm{h}}$ ia6 & $\mathrm{k}^{\mathrm{h}} \mathrm{ia}_{7}$ & $\mathrm{k}^{\mathrm{h}} \mathrm{ie}_{7}$ & $\mathrm{k}^{\mathrm{h}} \mathrm{ie}_{7}$ \\
\hline 蟻 & 歌 & 3止-支 & $\mathrm{K}$ & hia6 & hia7 & hia6 & gia7 & yia7 & yia7 \\
\hline
\end{tabular}

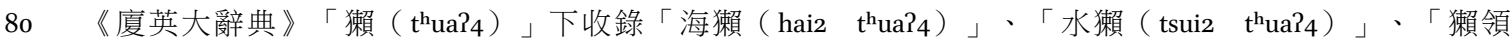
$\left(\mathrm{t}^{\mathrm{h}} \mathrm{ua} 4 \mathrm{niã2}\right) （$ 用海獺皮製作的領圈）」（Douglas1873： $564 ） ；$ 《福州方言詞典》收錄「獺」讀為 $\mathrm{t}^{\mathrm{h}} \mathrm{ia} 4$, 釋義「水獺、旱獺、海獺的統稱」（馮愛珍1998：397）。

81 閩語指稱「舉抬」動作的語詞, 閩南讀為 gia?8或kia?4, 閩東讀為kiak8, 該語詞應聯繫為漢語詞 $\ulcorner$ 揭」（參見楊秀芳2014），上古音歸屬祭部入聲。

82 《廈英大辭典》「癬（ $\mathrm{ts}^{\mathrm{h}} \mathrm{uã} 2 ） 」$ 釋義「eruptions or dirt on skin」，其下收錄「狗癬（ kau2 ts ${ }^{\mathrm{h}} \mathrm{uan} 2 ） 」$ 釋義 $\left\ulcorner\right.$ an eruption on the skin like ringworm or scrofulous eruptions $」 ，\left\ulcorner\right.$ 著風癬（ tiop8 hoj1 ts ${ }^{\mathrm{h}}$ ua $2 ） 」$ 釋義 $「$ to have a sort of itching eruption」（Douglas1873：91）。《福州方言詞典》收錄「癬」讀為 $\mathrm{ts}^{\mathrm{h}}$ iaj 2 , 釋義「由徽菌 引起的某些皮膚病, 可發生於手、足、頭等部位」, 其下收錄「生癬（ saj1 ts $\left.{ }^{\mathrm{h}} \mathrm{iaj} 2 ）\right\lrcorner （$ 馮愛珍1998： 280）。

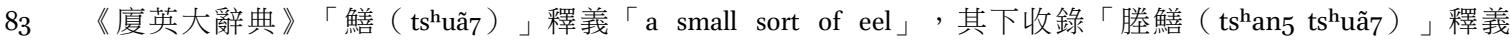
$\ulcorner$ a very small fresh-water eel having soft eatable bones $\lrcorner ，\left\ulcorner\right.$ 硬骨鱔（ jĩ kut4 ts ${ }^{\mathrm{h}}$ uã 7 ）」釋義 $「$ a salt-water sort with numerous hard bones, not good to eat」（Douglas1873：91）。《福州方言詞典》收錄「鱔」讀為 $\mathrm{ts}^{\mathrm{h}} \mathrm{h}_{\mathrm{ia}}$ ， 釋義「鱔魚」、「稱買賣田地產業的經紀人」（馮愛珍 $1998 ： 280$ ）。

84 閩南方言指稱 $「$ 發誓」為tsiu3 tsua3/7, 該語詞第一音節可合理聯繫為「咒」, 第二音節可合理聯繫為 $\ulcorner$ 誓」。《廣韻》收錄「咒（呪）」為職救切（中古章母3等宥韻去聲），釋義「呪詛」，「咒」的 聲、韻、調在閩南方言的規則音讀即為 tsiu3, 語義聯繫亦相當符合。《廣韻》收錄「誓」為時制切 （中古禪母 3 等祭韻去聲，上古祭部），釋義「誓約」，而古禪母在閩南有讀為ts-的演變規則，如 
（2）從歷史音韻規則來看：「掣入」屬古昌母祭部入聲, 中古進入薛韻。古昌母在 閩語今讀為 $\mathrm{ts}^{\mathrm{h}}$ - 為嚴整的規則讀法; 而古祭部入聲於舌尖聲母條件下在閩南方 言韻讀為-ua?，閩東方言韻讀為-iak，乃合於上述古歌祭元相應的層次韻讀規則 （如表9）；而古昌母屬清聲母，清聲母入聲今讀為陰入調亦合於規則。也就 是說，用力拉扯義的 $「$ 掣人」在今日閩南方言讀為 $\mathrm{ts}^{\mathrm{h}} \mathrm{ua} \mathrm{P}_{4}$, 閩東方言讀為 $\mathrm{ts}^{\mathrm{h}} \mathrm{iak}_{4}$, 聲、韻、調完全合於歷史演變規則。需要特別說明的是, 古漢語「厂」詞族中 表用力拉扯義另有 $「$ 把、/拽」，儘管古以母在閩語也有讀為 $\mathrm{ts}^{\mathrm{h}}$-的規則讀法，但 由於古以母屬濁聲母，而古濁母入聲今應歸讀陽入調，此與閩南 $\mathrm{ts}^{\mathrm{h}} \mathrm{ua} 4$ 、閩東 $\mathrm{ts}^{\mathrm{h}} \mathrm{iak} 4$ 陰入調的讀法不相符應, 因此本文認為閩南方言、閩東方言表拉扯義的 $\mathrm{ts}^{\mathrm{h}} \mathrm{ua} 4 / \mathrm{ts}^{\mathrm{h}} \mathrm{iak} 4$ 聯繫為「掣,」比聯繫為「把／拽」來得合適。至於引縱抽動義的 $\left\ulcorner\right.$ 掣去 $/$ 掱」為古昌母祭部去聲, 閩南方言規則音讀應為 $* \mathrm{ts}^{\mathrm{h}} \mathrm{ua}_{3}$, 但閩南表顫抖 義者今讀為入聲 $\mathrm{ts}^{\mathrm{h}} \mathrm{ua} \mathrm{P}_{4}$, 與表用力拉扯義者音讀相同，大概是北方漢語以去入 兩讀來分別率制抽動義與用力拉扯義，但閩語並未承繼「掣去」的率制本義， 抽動義「掣」為狀態動詞（如例 $34\left\ulcorner\right.$ 喙䈨咧 $\left.\mathrm{ts}^{\mathrm{h}} \mathrm{ua} 4 \mathrm{2}\right\lrcorner ） ，$ 拉扯義 $「$ 掣」為動作 動詞（如「 ts ${ }^{\mathrm{h}} \mathrm{ua} 4$ 喙䰅」），兩者在語法表現上即有差別，不需以去入兩讀來 加以辨義, 因此均讀為後起的入聲讀法。

\section{3 閩南、閩東表排泄義 $\mathrm{ts}^{\mathrm{h}} \mathrm{ua} 7 / \mathrm{ts}^{\mathrm{h}} \mathrm{ua} 4 / \mathrm{sie}_{7}$ 的討論}

本文第二節說明閩南方言表排泄義有兩個動作動詞：tsh ${ }^{\mathrm{h}} \mathrm{ua}$ 、 $\mathrm{ts}^{\mathrm{h}} \mathrm{ua} 4$ 。前者 $\mathrm{ts} \mathrm{s}^{\mathrm{h}} \mathrm{ua}$ 通常表 示不由自主地排尿，而且排泄的尿量頗多，但不能說 $「 * \mathrm{ts}^{\mathrm{h}} \mathrm{ua}$ 屎」。後者 $\mathrm{ts}^{\mathrm{h}} \mathrm{ua} \mathrm{P}_{4}$ 則表 示大小便失禁, 指向禁忍不住而點滴排泄出屎尿之意。閩東方言則未細分兩者, 表失 禁排泄義皆為 $\operatorname{sie}^{\circ}$ 。《廈門方言詞典》將表排泄義的 $\mathrm{ts}^{\mathrm{h}} \mathrm{ua} 7$ 寫為 $「$ 拽」，將 $\mathrm{ts}^{\mathrm{h}} \mathrm{ua}$ P 4 寫為

$\left\ulcorner\right.$ 掣」, 據此來看, 一般認為閩南表大量排泄義 $\mathrm{ts}^{\mathrm{h}} \mathrm{ua}$ 7與 4.1節所討論表引領義的 $\mathrm{ts}^{\mathrm{h}} \mathrm{ua} 7$ 有關，而表失禁排泄義 $\mathrm{ts}^{\mathrm{h}} \mathrm{ua}$ 2 4 則與 4.2節所討論表拉扯、顫抖義的 $\mathrm{ts}^{\mathrm{h}} \mathrm{ua}$ 4 有關。然而, 閩東方言相應的語詞讀為 $\operatorname{sie}_{7}$, 《福州方言詞典》寫為「泄」，而「泄」恰與本文所 討論的「把/拽」同屬「「」詞族。本小節將詳細討論閩南、閩東表排泄義的動詞來源 與發展。

\subsection{1 泄的語義用法}

根據《說文解字》（例91），「泄」為九江的一條水名，與今所通行的洩漏、排泄之 義似乎不直接相關；但上古漢語文獻中另有「泄泄」或「洩洩」一詞，如例（92）

$\ulcorner$ 泄泄其羽」意指羽翼奮然鼓動的狀態、例（93）「其樂也洩洩」意指愉悅舒散的狀 態, 其語義雖也異於洩漏、排泄之義，但奮發、舒散之義又與下文所論「因受牽引而 流動、由封閉而發散」的語義特性密切相應。《廣韻》收錄「泄」兩項音讀：一是餘 制切（以母祭韻去聲），釋義即《說文》所謂九江水名，85 而根據《經典釋文》，例

$\ulcorner+」$ 讀為tsap8、「上」讀為 tsiũ $6 /$ tsiõ 7 ; 古祭部有讀為 $-\mathrm{ua}$ 的演變規則，如 $\ulcorner$ 芥」讀為 kua3、 $\left\ulcorner\right.$ 蔡」讀為 $\mathrm{ts}^{\mathrm{h}} \mathrm{ua} 3$ 、「逝趙」讀為 $\mathrm{tsua} 3 / 7$; 古全濁去聲在閩南漳州歸讀陽去調, 泉州箇讀調不分陰陽 去。然則 $「$ 誓」的聲、韻、調在閩南方言可合理讀為 $t$ sua $/ 7$, 語義聯繫亦相當符合。且古漢語文獻中 即有「咒誓」一詞, 例如《敦煌變文》：「汝若今朝不信, 我設咒誓, 愿我七日之内命終, 死墮阿 鼻地獄。」（《敦煌變文集新書》，頁669）。

《廣韻》, 頁 $377-378$ 。 
（92）-（93）「泄/洩」亦同讀為以母祭部去聲；二則為私列切（心母薛韻入聲）, 釋義則為「漏泄也，歇也」；此兩種音義下皆註明「泄」與「洩」相同。86

（91）《說文解字》泄，水。受九江博安洵波，北入氏。从水业聲。87

（92）《毛詩・非風・雄雉》雄雉于飛, 泄泄其羽。

《正義》曰：毛言雄雉往飛向䧳雉之時, 則泄泄然鼓動其羽翼。以興宣公往起 就婦人之時，則奮訊其衣服。言志在婦人而已，不恤國之政事也。88

（93）《春秋左傳・隱公元年》公入而賦：「大隧之中, 其樂也融融。」姜出而賦： $\ulcorner$ 大隧之外, 其樂也洩洩。」遂為母子如初。

《正義》日：賦詩謂自作詩也。中融外洩，各自為韻。……融融，和樂；洩 洩, 舒散; 皆是樂之狀, 以意言之耳。 89

《說文解字》另外收錄有「渫」（例 94），釋義為「除去也」，意指去除汗穢，如例 （95）「井渫不食」以井水去汗清潔後卻沒人食用來比喻人潔身自持卻不受重用，段 注說明：後來表泄漏義的「泄/洩」即由去除義的「渫」引申變化而來。如例（96）以 煮美來說明「和」的意涵, 用水、火、醋、肉醬、鹽、梅子來烹煮魚肉, 用柴新炊

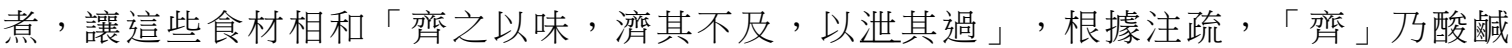
中和, 「濟」乃增益味道不夠的食材, 「泄」則是減損味道太強烈的食材; 這裡

$\ulcorner$ 泄」的減損義, 即去除過多的味道, 語義上與「渫」的去除義頗為相近。

（94）《說文解字》渫，除去也。从水枼聲。90

《段注》: 《井・九三》日：「井渫不食。」荀爽日：「渫去穢濁, 清潔之意 也。」按：凡言泄漏者，師此義之引伸。變其字爲泄耳。91

（95）《周易・井》九三：「井渫不食, 為我心惻, 可以波, 王明, 並受其福。」

《注》: 渫, 不停污之谓也。

《正義》日：井渫不食者，渫，治去穢污之名也，井被渫治，則清潔可 食。……為我心惻者, 為猶使也。井渫而不見食, 猶人脩己全潔而不見用, 使 我心中惻愴，故曰為我心惻也。92

（96）《春秋左傳 - 昭公二十年》和如美焉, 水、火、䤈、酦、鹽、梅, 以烹魚肉, 燀之以新, 宰夫和之, 齊之以味, 濟其不及, 以戋其過。

《正義》曰：醇，酢也; 醠，肉醬也；梅果實似杏而醋。……齊之者，使酸鰔 適中；濟益其味不足者；泄減其味大過者。93

古漢語文獻中的「泄/洩」多為漏泄義, 漏泄的對象可以是地氣、海水、氣味, 如例 （97）-（99），也可以是言語或事件，如例（100）-（102）; 前者多指向水或氣體由

86 《廣韻》, 頁 496。

87 《說文解字注》, 頁 539 。

88 《毛詩正義》, 頁 $234^{\circ}$

89 (晉) 杜預注, (唐) 孔穎達等正義：《春秋左傳正義》, 臺北：新文豐出版社, 2001 , 頁 79-80。

$90 「$ 枼」乃從「世」聲, 而「世」與「「」音義緊密相關。

91 《說文解字注》, 頁 569 。

92 《周易正義》, 頁 407-408。

93 《春秋左傳正義》, 頁 $2217-2219$ 。 
原來封閉不動的狀態透過某種縫隙率引而泄漏流動; 而後者進而引申為言語或事件由 不為人知的封閉狀態被某人牽引而泄漏傳播。據此來看上述「井葉」，如《管子・禁 藏》所言：「當春三月.$\cdots \cdots$ 杼井易水，所以去茲毒也。」94 此乃反映古人清潔井水的 方式為: 取出井底淤泥而使封閉不動的井水透過率引而流洩通暢, 故稱之為「渫 （泄）」；若然，未必如段注所言表漏泄義「泄」引申自去除義「渫」，而是「泄」、

$「$ 渫」皆表受牽引而流洩的漏泄之義。「渫/泄/洩」音讀相近，聲符均與「「」有 關，而語義上「由密閉不動受率引而流洩」亦與「厂」的拉引核心語義極為相關，故 本文認為「泄」與「抴/拽」同樣來自「「」的杽乳衍生。

（97）《禮記・月令》孟冬行春令，則凍閉不密，地氣上泄，民多流亡。95

（98）《莊子・秋水》天下之水，莫大於海，萬川歸之，不知何時止而不盈；尾 閭泄之，不知何時已而不虛。96

（99）《後漢書・王充王符仲長統列傳》後世聖人易之以棺槨, 桐木為棺, 葛采為 緘，下不及泉，上不泄自。97

（100）《史記・刺客列傳》丹所報，先生所言者，國大事也，願先生勿泄也。98

（101）《史記 · 吳太伯世家》吳人告敗於王夫差, 夫差惡其聞也。或泄其語, 吳王 怒，斬七人於幕下。99

（102）《論衡・語增》始皇知左右洩其言, 莫知為誰, 盡捕諸在旁者皆殺之。100

漏泄義與牽引義之間的語義關聯, 可以藉由「漏」的語義發展來加以聯繫。根據《說 文解字》（例103、104），「屚」為房屋有孔隙而雨水下漏, 而「漏」則本為計時器, 後來表洩漏義者通行為「漏」而「屚」則廢用。雨水下漏的原因是房屋有孔隙，亦即 房屋孔隙率引雨水發生滲漏。而「漏」的漏泄對象亦由水液引申為言語事件，如例 （105）以玉器漏水來比喻人君泄漏群臣言語之不當，「漏」乃與「泄」同用，如例 （106）。古漢語文獻中「漏」多作為漏泄義, 到了近代漢語發展出特殊的引誘義, 如 例（107）、（108），乃以若干特意的動作行為來引誘人上當，如前所言，漏泄義乃 $\ulcorner$ 由密閉不動的狀態受縫隙孔洞牽引而流洩、滲漏」，正如同人受若干特意的動作行 為率引而迷惑失常。據此，本文認為「泄/洩」的漏泄義乃反映縫隙的牽引力量，而

$\ulcorner$ 漏」的引誘義乃來自故意設陷阱如孔隙而引人滲入陷阱當中。

（103）《說文解字》屚，屋穿水下也。

《段注》：今字作漏，漏行而屚廢矣。漏者，以銅受水刻節也。101

（104）《說文解字》漏, 以銅受水, 刻節, 書夜百節。从水屚, 取屚下之義, 屚亦 聲。102

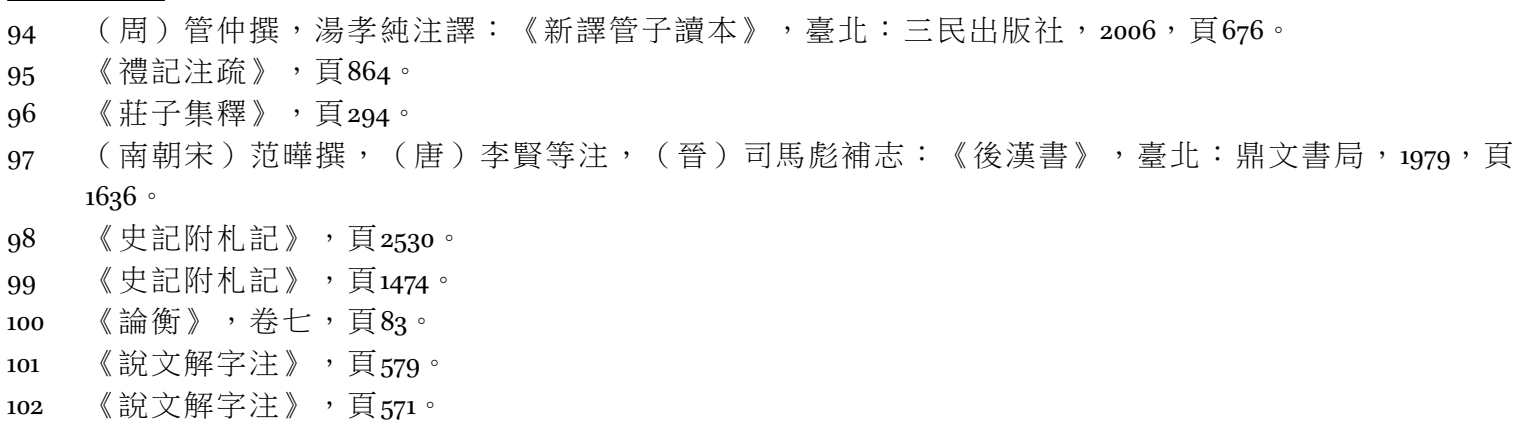


（105）《韓非子・外儲說右上》夫瓦器至賤也, 不漏, 可以盛酒。雖有乎千金之玉 巵，至貴，而無當，漏，不可盛水，則人孰注漿哉？今為人主而㖤其群臣之 語，是猶無當之玉巵也，雖有聖智，莫盡其術，為其漏也。103

（106）《春秋穀梁傳 ·文公六年》君漏言也。上泄則下闇, 下闇則上襲, 且闇且聾, 無以相通。104

（107）《水滸傳 ·第二十七回》因此特地說些風話，㖤你下手。105

（108）《水滸傳 . 第八十八回》原來番將不輸, 特地要賣箇破綻, 漏他來趕。106

漏泄的對象由外界的水、氣、言語、事件轉為身體內部的精魂、血液、水瀉、穢物

（例109-113），「泄/洩」進而衍生身體排泄義。例（109）、（110）表示「封閉體內的 精、血被大量泄漏出體外」，此二例「泄/洩」仍表一般漏泄之義; 而例（111）

$\ulcorner$ 泄注」、（112）「泄利」意指嚴重地下瀉，例（113）「泄穢」意指排泄屎尿一類穢 物, 這裡「泄」即專指將體內穢物排泄出體外的動作語義。

（109）《史記・扁鵲倉公列傳》言未卒, 因噓唏服臆, 魂精泄横, 流涕長湐。107

（110）《史記・扁鵲倉公列傳》至春果病，至四月，泄血死。108

（111）《史記・扁鵲倉公列傳》臣意未往診時, 齊太醫先診山跗病, 炎其足少陽脈 口, 而飲之半夏丸，病者即泄注，腹中虛。109

（112）《典論・論卻儉等事》議郎安平李覃學其辟穀, 餐伏苓, 飲寒水, 中迣利, 殆 至隕命。110

《釋名·釋疾病》：「泄利，言其出漏泄而利也。」畢沅《疏證》：「泄利， 今之所謂水瀉也。」111

（113）《大藏經 ·經律異相》十一日膖臭, 縱廣二千五百里, 滿中膿血。此人生時以 不善心入聖人室, 失氣泄穢。受罪二百四十歲。後生貧賤人中身體常臭。112

總合以上討論「泄/洩」的語義用法之發展演變如表10：

（1）「泄/洩」有兩種音讀：一是古以母祭韻去聲, 表示發動舒散的狀態, 並以此 為九江水名, 下文稱之為「泄去」; 二是古心母薛韻入聲, 語義由漏泄外部水 氣、言語轉為排泄體內水液精氣, 下文稱之為「泄人」。

（2）本文認為「泄/洩」也來自「厂」詞族的杽乳，113其兩類語義皆衍生自率引之 義。相較來看, 牽引動作乃施力者拉動不具反向抗力的受事者朝向相同方向前 進, 著眼於受事者受到率引、由靜止而發動、舒散的狀態，便發展出「泄泄/

\footnotetext{
103 （周）韓非撰，（清）顧實圻識誤：《韓非子》, 臺北：中華書局, 1977 , 卷十三, 頁 8。

104 （晉）范寧注, （唐）楊士勛疏：《春秋穀梁傳注疏》, 臺北：新文豐出版社, 2001, 頁 289 。

105 《水湤傳》, 頁 380 。

106 《水澈傳》, 頁 $1147^{\circ}$ 。

107 《史記附札記》，頁2790。

108 《史記附札記》, 頁 2807 。

109 《史記附札記》, 頁 2802 。

110 (魏) 曹丕撰：《典論》, 北京：中華書局, 1985 , 頁 4。

111 （漢）劉熙撰, （清）畢沅疏證：《釋名疏證》, 北京：中華書局, 1985, 頁 253。

112 《經律異相》, 卷五十, 頁 364 。

113 關於「厂」詞族更多相關語詞的探究，我們將另文析論。
} 
洩洩」等狀態動詞; 而著眼於封閉空間中縫隙孔洞的率引力量，拉動原來封閉 的水氣、言語發散而出，便發展出泄漏的動作語義；再以泄漏義為基礎，其受 事者若轉為體內的水液精氣便形成身體排泄義。

表 10

$「$ 泄/浅」的語義發展演變

\begin{tabular}{|c|c|c|c|c|c|c|}
\hline \multicolumn{2}{|c|}{ 泄/洩 } & \multicolumn{3}{|c|}{ 受事者 } & 力量大小 & 施力者 \\
\hline 牽引義 & 抴舟 & [-反抗力] & [+移動 ] & - & [抗力<施力] & - \\
\hline 發動、舒散 & 泄泄/洩洩 & [-反抗力] & $\begin{array}{c}\text { [+由靜止而 } \\
\text { 發動] }\end{array}$ & - & [抗力<施力] & - \\
\hline 漏洩義 & $\begin{array}{c}\text { 地氣上泄 } \\
\text { 泄其語 }\end{array}$ & [-反抗力] & $\begin{array}{c}\text { [+由封閉而 } \\
\text { 發散] }\end{array}$ & $\begin{array}{c}\text { [-施力者所 } \\
\text { 有] }\end{array}$ & [抗力<施力] & - \\
\hline 排泄義 & 泄穢 & [-反抗力] & $\begin{array}{c}\text { [+由體內而 } \\
\text { 排外] }\end{array}$ & $\begin{array}{c}\text { [+施力者所 } \\
\text { 有 }]\end{array}$ & [抗力<施力] & - \\
\hline
\end{tabular}

4.3.2＼cjkstart閩南、閩東表排泄義之語詞來源

閩東方言表排泄義的 $s i e 7$ 與閩南方言表大量排泄義的 $t s^{\mathrm{h}}{ }^{\mathrm{u}} 7$ 應聯繫為表排泄義的「泄」， 但音讀上卻是反映去聲讀法; 而閩南表失禁排泄義的 $\mathrm{ts}^{\mathrm{h}} \mathrm{ua} 24$ 則有兩種解釋方案：一是 聯繫為前述表引縱抽動的「掣」，二是使用「泄」的入聲讀法（私列切）來區辨語 義。下面分語義、歷史音韻兩方面進行討論。

（1）從語義對應關係來看：古漢語詞「泄」由漏泄義發展出排泄體內穢物之義，大 致相應於閩南、閩東表排泄義的 $\mathrm{ts}^{\mathrm{h}} \mathrm{ua}$ 、 $\mathrm{sie}^{\circ}$ 。如表11所示, 表排泄義的「泄」 乃隨順體內水液精氣由縫隙向外排出, 主事者與受事者的動力方向一致, 受事 者不具抗力、主事者也不進行反向牽制; 閩南表大量排泄義的 $\mathrm{ts}^{\mathrm{h}} \mathrm{ua}$ 與此特性 相同，乃主事者無意識下、不由自主地排泄出大量尿液。由於「泄」的洩漏排 泄義乃從率引之義引申而來, 若將 $\mathrm{ts}^{\mathrm{h}} \mathrm{ua}$ 、 $\mathrm{sie}$ 聯繫為表率引、拖曳「把/曳」也 無不可; 不過若著眼於被牽引的尿液乃由封閉的體內向外舒散, 而非主事者對 受事者的引領、隨帶, 我們認為還是聯繫為表排泄義的「泄」更為合適。

表11閩南表排泄義語詞與「泄、掣」的語義比較

\begin{tabular}{|c|c|c|c|c|c|c|}
\hline \multicolumn{2}{|r|}{ 閩南 } & \multicolumn{3}{|c|}{ 受事者 } & 力量大小 & 施力者 \\
\hline 泄 & 排泄義 & [-反抗力] & [+由體內而排外] & [+施力者所有] & [抗力<施力 ] & [-控制] \\
\hline 掣 & 引縱抽動義 & [+反抗力 ] & [土移動] & [土施力者所有] & [抗力 $\geqq$ 施力 ] & [土控制] \\
\hline & $\mathrm{ts}^{\mathrm{h}} \mathrm{ua} 7$ 尿 & [-反抗力] & [+由體內而排外] & [+施力者所有] & [抗力<施力 ] & [-控制] \\
\hline & $\mathrm{ts}^{\mathrm{h}} \mathrm{ua} 4$ 尿 & [+反抗力] & [+由體內而排外] & [+施力者所有] & [抗力 $\geqq$ 施力 ] & [ 控制] \\
\hline
\end{tabular}


閩南方言另有表失禁排泄義的 $\mathrm{ts}^{\mathrm{h}} \mathrm{ua} 4$, 語義特點如下：（1） ts $\mathrm{h}^{\mathrm{h}} \mathrm{ua} 4$ 往往是有意識的禁 忍卻禁忍不住；（2） $\mathrm{ts}^{\mathrm{h}} \mathrm{ua} 4$ 可以排泄大小便；（3） $\mathrm{ts}^{\mathrm{h}} \mathrm{ua} 4$ 通常指向點滴排泄而非大 量。相較於表大量排泄的 $\mathrm{ts}^{\mathrm{h}} \mathrm{ua}$, 如表 11 所示, $\mathrm{ts}^{\mathrm{h}} \mathrm{ua}$ 4 4 乃主事者有意識控制卻又控制不 住地泄漏出少量屎尿，此動作事件中，主事者與受事者的動力方向相反，施力與抗力 之間形成拉鋸。此與前述表引縱抽動的「掣」詞義非常相近，惟抽動義「掣」多做為 狀態動詞, 且受到引縱而抽動者未必發生移動, 此與 $\mathrm{ts}^{\mathrm{h}} \mathrm{ua}$ ?4做為動作動詞, 且引縱屎 尿由體內而外的趨動方向不同。據此，將失禁排泄義的 $\mathrm{ts}^{\mathrm{h}} \mathrm{ua} 4 \mathrm{4}$ 聯繫為「掣」在語義上 沒有問題，但語法表現上較無法形成緊密對應。本文提出另外一種解釋方案：閩南失 禁排泄義的 $\mathrm{ts}^{\mathrm{h}} \mathrm{ua} 4$ 也可以聯繫為「泄」，在同樣排泄動作的語義、語法基礎之上，主 事者與受事者的動力方向轉為相反, 主事者需要施力加以牽制卻又控制不住而漏泄, 此乃相應於「泄」特別指稱病狀的下瀉（泄注、泄利），為了區別於上述表大量排泄 的 $\mathrm{ts}^{\mathrm{h}} \mathrm{ua}$ ，閩南方言採取「泄」另一讀法來辨義。

（2）從歷史音韻規則來看：閩南方言的 $\mathrm{ts}^{\mathrm{h}} \mathrm{ua}$ 、閩東方言的 $\mathrm{sie} 7$ ，在音讀上應來自 餘制切的「泄去，古以母與邪母同讀為 $\mathrm{ts}^{\mathrm{h}}$-或 $\mathrm{s}$-為閩語聲母的特點（表 8 ），古祭部去 聲於舌尖聲母條件下在閩南方言韻讀為-ua, 而閩東方言韻讀為-ie乃屬另一項中古祭韻 的白讀層次，如表 9 閩東「誓逝」韻讀即為-ie；古以母去聲今讀為陽去調亦合於規 則。儘管《廣韻》記為餘制切的「泄去」釋義為水名, 或是表示發動舒散的狀態, 但 從同族語詞衍生的觀點來看，「泄」表發動舒散狀態或表泄漏動作皆來自率引義

$\ulcorner\Gamma 」$ 的杽乳衍生, 則後來發展出排泄義的「泄」在閩語也可能還是保留原來去聲的 音讀。而閩南方言表失禁排泄義的 $\mathrm{ts}^{\mathrm{h}} \mathrm{ua} 4$, 若聯繫為引縱抽動的「掣」，音讀如 4.2 節 所述符合歷史演變規則; 若聯繫為排泄義的「泄人」，古心母在閩南方言有讀為 $\mathrm{ts}^{\mathrm{h}}$-的 白讀表現，例如：臊 $\mathrm{ts}^{\mathrm{h}} \mathrm{O}$ 、髧 $\mathrm{ts}^{\mathrm{h}} \mathrm{iu}$ 、醒 $\mathrm{ts}$ h $\mathbf{2} 2$ 等, 古祭部入聲於舌尖聲母條件下在閩南 方言韻讀為-ua?，合於上述古歌祭元相應的層次韻讀規則（如表 9）；古心母為清聲 母，清聲母入聲今讀為陰入調亦合於規則。據此，閩南方言或以兩個不同語詞「泄、 掣」來指稱不同的排泄方式；或者承繼古漢語詞表泄漏、排泄義的「泄」，但有其形 態上的個別發展：以基底音讀餘制切（ts ${ }^{\mathrm{h}} \mathrm{ua} 7$ ）來指稱不由自主地大量排泄尿液，另以 後起私列切（ $\mathrm{ts}^{\mathrm{h}} \mathrm{ua} 4 \mathrm{4}$ ）來指稱禁忍不住而點滴排泄屎尿, 此二音讀兼具聲母清濁、聲 調去入的別義方式。閩東方言則僅使用「泄」的基底音讀餘制切（ sie $）$ 來同時指稱 大量排尿及屎尿失禁，另外也使用同義語詞「漏（lau3）」指稱屎尿失禁。

本文藉由菓整、析論古漢語「把/曳/掣/泄」的語義用法及其音義衍生脈絡，對照閩 南、閩東若干相關語詞的語義用法及其發展演變, 進而探究兩者之間密切的同源關係 以及閩語內部的個別發展, 重要結論如下：

1. 古漢語「把/曳/掣/泄」的語詞關係：

（1）「把去」、「史」兩詞皆從「「」杽乳衍生：「把去」本為橫向率引之義，專指 船旁撥水、荤引船隻前進的短獎，引申為率引他人之義；「曳」為拖曳後物之 義，所拖曳者多為主事者所擁有的一小部分，因此往往隨帶在身後。「曳」的 拖曳義進一步發展出用力拉扯義，拉扯動作欲使受事者從原來固著處斷裂或分 離, 字形上後起「抴, /拽」。 
（2）「掣」原為率制之義，所牽制者往往具有反向抗力，主事者與受事者形成相反 方向的拉鋸；在「反向拖拉而率制某物」的語義基礎之上，「掣」又衍生引縱 抽動的狀態動詞用法; 「掣」的牽制義進一步也發展出用力拉扯義, 後續又轉 為抽取義, 音讀上則出現入聲讀法。

（3）「泄/洩」也來自「厂」杽乳衍生，一是表示受到牽引而發動舒散的狀態，二 是表示受到率引、由封閉而外漏的動作語義，後續又發展出身體排泄義。

（4）「掣」與「把去/曳」共同具有「拉引」動作的核心語義，因其受事賓語特性相 異，兩者詞義有所差別，但後續都發展出用力拉扯的語義。從語義的源流發展 上來看，「掣」與「把去曳」極為密切相關；然而，來自舌根聲類的「掣去」 與來自舌尖聲類的「把去/史/泄」在歷史音讀上尚未能充分論證同出一源，有待 未來繼續深入考證。

2. 閩南、閩東若干相關語詞與 $「$ 把/曳/掣/泄」的同源關係, 以及閩語內部的個別發 展, 如表12所示, 說明如下:

（1）閩南方言表引領義 $\mathrm{ts}^{\mathrm{h}} \mathrm{ua}$ 應聯繫為表率引、拖曳義的「抴去/曳」; 閩南內部再個 別發展出隨帶義、討娶義、引致義。

（2）閩南方言、閩東方言表拉扯義 $\mathrm{ts}^{\mathrm{h}} \mathrm{ua} 4$ 、 $\mathrm{ts}^{\mathrm{h}} \mathrm{iak} 4$ 應聯繫為表用力拉扯義的 $「$ 掣入」; 閩南同時繼承「掣去」的引縱抽動義，但音讀上讀為後起的入聲讀法；閩東則 由拉扯義又個別發展出拉傷義。

（3）閩南表大量排泄義為 $\mathrm{ts}^{\mathrm{h}} \mathrm{ua}$ ，表失禁排泄義則為 $\mathrm{ts}^{\mathrm{h}} \mathrm{ua} 4$; 閩東指稱兩種排泄義均 為 $\operatorname{sie}_{7}$ 。閩南 $\mathrm{ts}^{\mathrm{h}} \mathrm{ua} 7$ 、閩東 $\operatorname{sie} 7$ 應聯繫為表排泄義的「泄人」，但音讀上保留去聲 的基底音讀。閩南表失禁排泄義的 $\mathrm{ts}^{\mathrm{h}} \mathrm{ua} 4$ 則有兩種可能的語詞來源：一是聯繫 為表引縱抽動的「掣」，語義貼近但語法表現相異；二是同樣聯繫為表排泄義 $\left\ulcorner\right.$ 泄人」，此乃為了區別於上述表大量排泄的 $\mathrm{ts}^{\mathrm{h}} \mathrm{ua}$, 閩南內部乃以「泄」的兩 種音讀變異（餘制切、私列切），包括聲母清濁、聲調去入來區別兩種排泄 義，而閩東僅使用濁母去聲一讀來同時指稱兩種排泄情形。

表12閩語「抴/曳/㨻/泄」的承繼與個別發展

\begin{tabular}{|c|c|c|c|c|}
\hline 古漢語 & \multicolumn{2}{|r|}{ 承繼古漢語 } & \multicolumn{2}{|r|}{ 個別發展 } \\
\hline $\begin{array}{l}\text { 抴去曳：牽引、拖曳 } \\
\text { 【餘制切】 }\end{array}$ & $\rightarrow$ & ts ${ }^{\text {hua }}$ ：引領 & $\begin{array}{l}\rightarrow \\
\rightarrow \\
\rightarrow\end{array}$ & $\begin{array}{l}\text { 隨帶義 } \rightarrow \text { 隨帶照顧 } \\
\text { 討娶義 } \\
\text { 引致義 }\end{array}$ \\
\hline $\begin{array}{l}\text { 掣去: 引縱抽動【尺制切】 } \\
\text { 掣人: 用力拉扯【昌列切】 }\end{array}$ & $\begin{array}{l}\rightarrow \\
\rightarrow\end{array}$ & $\begin{array}{l}\mathrm{ts}^{\mathrm{h}} \mathrm{ua} 4 \mathrm{4} \text { : 顫抖 } \\
\mathrm{ts}^{\mathrm{h}} \mathrm{ua}_{4} / \mathrm{ts}^{\mathrm{h}} \mathrm{iak}_{4} \text { : 用力拉扯 }\end{array}$ & $\begin{array}{l}(\rightarrow \\
\rightarrow\end{array}$ & $\begin{array}{l}\text { 失禁排泄 ) } \\
\text { 扯動拉傷 }\end{array}$ \\
\hline $\begin{array}{l}\text { 泄 }{ }_{\text {去 }} \text { 發動舒散【餘制切】 } \\
\text { 泄 }_{人} \text { : 漏泄、排泄【私列切】 }\end{array}$ & $\rightarrow$ & 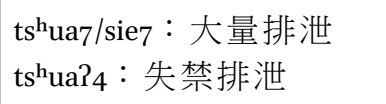 & & \\
\hline
\end{tabular}




\section{引用文獻}

\section{一、傳統文獻}

（周）呂望撰：《六鞱》。臺北：廣文書局, 1991。

（周）荀況撰，（唐）楊倞注：《荀子》。北京：中華書局， 1985 。

（周）莊周撰, （晉）郭象注, （唐）陸德明釋文, （唐）成玄英疏, (清) 郭慶藩集釋 : 《莊子集釋》。

臺北：臺灣中華書局, 1980 。

（周）管仲撰，湯孝純注譯：《新譯管子讀本》。臺北：三民出版社，2006。

（周）韓非撰，（清）顧實圻識誤：《韓非子》。臺北：中華書局，1977。

（漢）毛公傳，（唐）孔穎達等正義：《毛詩正義》。臺北：新文豐出版社，2001。

（漢）王允撰：《論衡》。北京：中華書局, 1985 。

(漢) 司馬遷撰, (南朝宋) 裴駰集解, (唐) 司馬貞索隱, 張守節正義：《史記附札記》。臺北：鼎文

書局, 1979 。

（漢）班固撰，（唐）顔師古注：《漢書》。臺北：鼎文書局，1979。

（漢）許慎撰, (清) 段玉裁注：《說文解字注》。臺北：藝文印書館, 1989 。

（漢）趙岐注，（宋）孫菡疏：《孟子注疏》。臺北：新文豐出版社，2001。

（漢）劉向撰：《說苑》。臺北：臺灣中華書局, 1981。

（漢）劉向編集，（清）王逸章句：《楚辭》。北京：中華書局, 1985 。

（漢）劉熙撰，（清）畢沅疏證：《釋名疏證》。北京：中華書局，1985。

（漢）鄭元注, (唐) 孔穎達等正義：《禮記注疏》。臺北：新文豐出版社, 2001。

（漢）《黃帝內經：靈樞》。臺北：廣文書局, 1991。

(三國) 王肅注：《孔子家語》。臺北：臺灣中華書局，1981。

（魏）王弼、韓康伯注, (唐) 孔穎達等正義：《周易正義》。臺北：新文豐出版社, 2001 。

（魏）曹丕撰 : 《典論》。北京：中華書局, 1985 。

(晉) 干寶撰, 曹光甫、王根林校點：《搜神記》。上海：上海古籍出版社, 2012 。

(晉) 杜預注, (唐) 孔穎達等正義：《春秋左傳正義》。臺北：新文豐出版社, 2001。

（晉）范寧注, (唐) 楊士勋疏：《春秋穀梁傳注疏》。臺北：新文豐出版社, 2001。

(晉) 郭璞注, (宋) 邢昺疏：《爾雅注疏》。臺北：新文豐出版社, 2001 。

(晉) 陳壽撰, (南朝宋) 裴松之注《三國志》。臺北：鼎文書局, 1979。

（晉）葛洪撰：《抱朴子》。臺北：臺灣商務印書館，1979。

（晉）釋法護譯：《生經》，收錄於《中華大藏經》第三十四冊。上海：中華書局, 1988 。

( 後秦) 佛陀耶舍、釋佛念譯 : 《佛說長阿含經》, 收錄於《乾隆大藏經》第五十冊。臺北：新文豐出版 社, 1998 。

（北魏）釋慧覺譯：《賢愚經》，收錄於《中華大藏經》第五十一冊。上海：中華書局，1992。

（南朝宋）范曄撰, (唐) 李賢等注, (晉) 司馬彪補志：《後漢書》。臺北：鼎文書局, 1979 。

(南朝宋) 劉義慶撰, (梁) 劉孝標注, 朱鑄禹彙校集注：《世說新語彙校集注》。上海：上海古籍出版 社, 2002。

（梁）釋寶唱集：《經律異相》，收錄於《中華大藏經》第五十三冊。上海：中華書局，1992。

（隋）闍那崛多譯：《佛本行集經》，收錄於《中華大藏經》第三十五冊。上海：中華書局，1989。

(唐) 王冰編次, (宋) 高保衡、林億校正, 吳潤秋整理：《素問》。海口：海南國際出版中心, 1996 。

(唐) 房玄齡等撰 : 《晉書》。臺北：鼎文書局，1979。

（唐）陸德明撰：《經典釋文》。上海：上海古籍出版社, 2013 。

(南唐) 靜、筠二禪師編撰, 孫昌武、衣川賢次、西口芳男點校：《祖堂集》。北京：中華書局, 2007 。

(宋) 丁度等編《集韻》。臺北：學海出版社，1986。

（宋）成無已撰：《傷寒明理論》。北京：中華書局, 1985 。 
(宋) 陳彭年等編撰 : 《廣韻》。臺北 : 洪葉文化, 2001 。

（宋）黎靖德編, 王星賢點校：《朱子語類》。北京：中華書局, 1986。

（明）張自烈撰，（清）廖文英編：《正字通》。北京：中國工人出版社，1996。

（明）吳承恩撰, 徐少知校, 朱䑣、周中明注：《西遊記校注》。臺北：里仁書局, 1996 。

(明) 施耐庵撰：《水澈傳》。臺北：桂冠圖書, 1992 。

（清）朱駿聲撰：《說文通訓定聲》。臺北：京華書局, 1970。

（現代）潘重規編著：《敦煌變文集新書》。臺北：文津出版社, 1994。

（現代）吳守禮校註：《明嘉靖刊荔鏡記戲文校理》。臺北：從宜工作室, 2001。

（現代）吳守禮校註：《清順治刊荔枝記戲文校理》。臺北：從宜工作室, 2001。

中央研究院歷史語言研究所：「漢籍電子文獻資料庫」（http://hanji.sinica.edu.tw/）。

\section{二、近人論著}

Douglas, Carstairs. 1873. Chinese-English dictionary of the vernacular or spoken language of Amoy. (廈英大辭典) Taipei, Taiwan, R.O.C: SMC Publishing Inc. ( 1990 ).

中國社會科學院與澳大利亞人文科學院合編. 1988. 《中國語言地圖集》。香港：朗文出版社。

古田縣地方志編纂委員會. 1997. 《古田縣志》（方言志部分）。北京：中華書局。

李方桂. 1998. 《上古音研究》。北京：商務印書館。

李如龍、潘渭水. 1998. 《建甌方言詞典》。南京：江蘇教育出版社。

杜佳倫. 2014. 《閩語歷史層次分析與相關音變探討》。上海：中西書局。

周法高. 1962. 《中國古代語法・構詞編》。台北：中央研究院歷史語言研究所。

周長楫. 1998. 《廈門方言詞典》。南京：江蘇教育出版社。

林倫倫. 1996. 《澄海方言研究》。汕頭：汕頭大學出版社。

林連通（主編）. 1993. 《泉州市方言志》。北京：社會科學文獻出版社。

林寒生. 2002. 《閩東方言詞彙語法研究》。昆明：雲南大學出版社。

林寶卿. 1992. 〈漳州方言詞彙〉, 《方言》2：151-160、3：230-240。

侯精一. 2002. 《現代漢語方言概論》。上海：上海教育出版社。

柘榮縣地方志編纂委員會. 1995.《柘榮縣志》（方言志部分）。北京：中華書局。

秋谷裕幸、陳澤平. 2012.《閩東區古田方言研究》。福州：福建人民出版社。

秋谷裕幸. 2010. 《閩東區福寧片四縣市方言音韻研究》。福建：福建人民出版社。

胡萬川（主編）.1996.《梧棲鎮閩南語故事集（一）》。豐原：臺中縣立文化中心。

胡萬川（主編）、1996-7.《清水鎮閩南語故事集（一）、（二）》。豐原：臺中縣立文化中心。

胡萬川（主編）。2001.《臺南縣閩南語故事集（一）、（二）、（三）、（四）、（五）、（六）》。新

營：臺南縣文化局。

馬重奇. 1993.〈漳州方言同音字匯〉，《方言》3：199-217。

張振興. 1992.《漳平方言研究》。北京：中國社會科學出版社。

梅祖麟. 2000a. 〈方言本字研究的兩種方法〉, 《梅祖麟語言學論文集》, 403-422。北京：商務印書館。

梅祖麟. 200ob. 〈四聲別義中的時間層次〉, 《梅祖麟語言學論文集》, 306-339。北京：商務印書館。

陳章太、李如龍. 1991. 《閩語研究》。北京：語文出版社。

馮愛珍. 1993. 《福清方言研究》。北京：社會科學文獻出版社。

馮愛珍. 1998. 《福州方言詞典》。南京：江蘇教育出版社。

楊秀芳. 1999. 〈方言本字研究的探義法〉, In Alain Peyraube and Chaofen Sun eds., Linguistic Essays in Honor of Mei

Tsu-Lin : Studies on Chinese Historical Syntax and Morphology. 299-326 • Paris: Ecole des Hautes Etudes en Sciences Sociales,

Centre de Recherches Linguistiques sur l'Asie Orientale.

楊秀芳. 2000. 〈方言本字研究的觀念與方法〉, 《漢學研究》第18卷特刊：111-146。

楊秀芳. 2009. 〈詞族研究在方言本字考求上的運用〉, 《語言學論叢》40：194-212。 
楊秀芳.2014. 〈古籍與方言所見「揭」的形態變化〉，《東海中文學報》28：203-226。

楊秀芳. 2017. 〈漢語形態構詞的多樣性與多層性〉, 《中國語言學集刊》（Bulletin of Chinese Linguistics）10： $298-328$ 。

龔煌城. 2000. 〈從漢藏語的比較看上古漢語的詞頭問題〉, 《語言暨語言學》1.2: 39-62。收錄於（2004） 《漢藏語研究論文集》, 161-182。北京：北京大學出版社。

龔煌城. 2001. 〈上古漢語與原始漢藏語帶 $\mathrm{rm}$ 與 1 複聲母的構擬〉, 《臺大文史哲學報》54：1-36。收錄於

（2004）《漢藏語研究論文集》，183-211。北京：北京大學出版社。

龔煌城. 2004. 《漢藏語研究論文集》。北京：北京大學出版社。 


\title{
The Historical Evolution of “Yi (抴/曳)” and “Che (掣)” and the Relevant Development in Some Min Dialects
}

\author{
Chialun Tu \\ National Sun Yat-sen University \\ raindoo@mail.nsysu.edu.tw
}

\begin{abstract}
In this paper, I sort the meanings and usages of the words "ts ${ }^{\mathrm{h}} u a 7^{\text {" and "ts }}$ ua?4" of Southern Min, and the relevant words of Eastern Min are listed as well. In the meantime, I analyze the meanings and usages of the words “Yi (把/曳)" and "Che (掣)" in archaic and ancient Chinese books which may originate in the same word family, and differentiate the historical evolution of them. And then based on the correspondences both of the sounds and semantic features, I make the connections between the words of Min dialects and their Chinese cognates in Archaic and Ancient Chinese.
\end{abstract}

\section{Keywords}

Min dialect - Yi (把/曳) - Che (㨻) - cognate words - word family 